\title{
A Comparative Analysis of Shina and Kashmiri Vocabularies
}

\author{
Ruth Laila Schmidt and Vijay Kumar Kaul \\ Oslo and Dehra Dun
}

\begin{abstract}
This paper presents lists of core vocabulary in ten dialects of Shina and Kashmiri, discussing in detail the lexical and phonological data contained in the Shina lists, with special attention to language contact phenomena. A few salient Shina grammatical features, from ancillary data, also point to contact with surrounding languages: the agent case markers, subject-verb concord, and suffix-noun concord in the possessive case.

A table of selected cognates presents a capsule overview of the lexical variation encountered in this project. It shows that Shina and Kashmiri do not share a large number of cognates even in a selective list, and that the phonological development of cognates has been strikingly different.

Loanwords are an important clue to influence from surrounding languages on Shina. Lists of loanwords show that while all Shina dialects have been in contact with Burushaski to a greater or lesser extent, there are also varying degrees of influence from especially Kashmiri, Persian (earlier the official language of the Kashmir state) and Tibetan.

The geographical sources of contact phenomena are examined to see if they correspond to Radloff"s (1992) "geographical centers of Shina".
\end{abstract}


Keywords: Shina, Burushaski, Kashmiri, Pashto, Persian, Tibetan; language contact, lexical variation.

\section{Introduction}

The purpose of this paper is to summarize the lexical and phonological data contained in ten lists of Shina and Kashmiri core vocabulary (attached as the second section of this paper beginning on p. 258). Most of these word lists were collected in the early 1980s in India and Pakistan for six dialects of Shina: Gilgiti, Kohistani, Astori, Guresi, ${ }^{1}$ Drasi and Brokskat, and four dialects at the time thought to belong to Kashmiri: Kashmiri itself, Kashtawari, Poguli and Siraji of Doda. This data has never been published. Grammatical data was also collected for the Kohistani, Guresi and Drasi dialects, but this will be the subject of separate papers. ${ }^{2}$

The word lists initially consisted of 280 core vocabulary items in eleven semantic areas of (1) body parts, (2) terms for kin and human beings, (3) human artifacts, (4) natural and weather phenomena, (5) time and space, (6) earth, (7) animals, (8) the plant world,

1 According to Grierson 1919: 174, the valley is known as Gurais in English and Gurēz in Persian. The speakers reported its indigenous name as Guráai.

2 The Gilgiti word list was originally provided by Prof. Georg Buddruss with Amin Zia, native of Gilgit. It was subsequently revised by Shakeel Ahmad Shakeel, native of Bhasin village, living in Gilgit all his life. The Kohistani word list was provided by Muhammad Manzar Zarin of Palas, living in Rawalpindi, and augmented by Razwal Kohistani, native of Palas now living in Rawalpindi. The Astori word list was provided by Begum Latif Anwar, native of Astor, now married into Chalt village in Nager. Word lists for the Tilel and Gures valleys were provided by Abdur Rahim Sheikh and Ashraf Sahil; the Drasi word list was provided by Shafi Drasi of Kargil, and the Brokskat word list by Stanzin Khurpa of Garkhon and Miskin Tshiring of Batalik.

The Kashmiri word list was provided by Vijay Kumar Kaul of Adoora village, Kashmir, and amplified from published sources. The Kishtawari word list was provided by S.L. Sharma of Kishtwar. The Poguli word list was provided by Manzoor Pogli of Banihal. The Siraji word list was provided by Nazir Ahmad of Kashtigarh, Doda. Vijay Kumar Kaul was research associate in Indian Kashmir, collecting the Drasi, Brokskat, Kishtawari, Poguli and Siraji lists, and helping to transcribe them.

The word lists were elicited in Urdu. 
(9) common verbs, (10) common adjectives, and (11) pronouns and miscellaneous. A supplementary word list of 36 additional items from Fussman's (1972) linguistic atlas was later collected from five of the Shina dialects (all except Brokskat). From the resulting list, 19 items were eventually discarded as being of little etymological or cultural interest, i.e., all the dialects presented borrowings, or the phenomenon was unknown, or there was no name for it. The remaining 297 items from the combined word lists form the basis of this paper.

A count of the shared core vocabulary (based on items 1-2493) found that Gilgiti Shina shares 77 per cent of its core vocabulary with Kohistani Shina, 76 per cent with Guresi, 71 per cent with Astori, 69 per cent with Drasi and 45 per cent with Brokskat. Kashmiri, on the other hand, shares only 27 per cent of its core vocabulary with Gilgiti Shina, including many cognates whose relationship is not entirely transparent, for example: Gilgiti cúrko and Kashmiri tsok, both meaning 'sour'; Gilgiti hat and Kashmiri athi, both meaning 'hand'. (If cognates had lost all trace of phonological similarity, for example Gilgiti záa and Kashmiri bo'y 'brother', they were not counted.)

Radloff 1992, using a different vocabulary inventory, found only 65 per cent of lexical similarity between the Shina of Gilgit and that of Jalkot in Kohistan, and 63 per cent with that of Palas in Kohistan). She found 77 per cent lexical similarity between Gilgiti and Astori and 76 per cent similarity between Gilgiti and Drasi. Radloff's lists contain many of the same items as ours, but in addition contain the names of many foodstuffs, tools and implements which ours do not; instead of collecting the infinitives of verbs, she collected imperative forms and short sentences. Radloff's calculations are borne out by the results of recorded text testing, which showed that the Kohistan subjects scored only 66 per cent correct responses when asked to

3 Items 250-267 were omitted because many of the choices for pronouns were arbitrary; the supplementary list is omitted because it was not collected for all dialects. Because the responses to these items included many synonyms, the number of Gilgiti words $=288$. These words had 221 easily recognizable cognates in Kohistani, 218 cognates in Guresi, 204 cognates in Astori, 200 cognates in Drasi and 131 cognates in Brokskat. 
answer questions about a recorded text in the Gilgiti dialect. The Astor subjects however scored 90 per cent. (The Guresi dialect lies outside Radloff's sampling area.) Radloff's results are relevant for our own data, and are taken into account in this paper.

The Shina vocabulary items in our lists are represented in phonemic or near-phonemic transcription. ${ }^{4}$ The pitch accent is shown in the Gilgiti, Kohistani, Guresi, Astori and Drasi entries. ${ }^{5}$ The phonemic inventory for Brokskat is not finalized, and the transcription of Brokskat is semi-phonemic. A falling pitch could be heard on some items, but we could not hear a rising pitch on any item, and could not exclude the possibility that the falling pitch resulted from list intonation. Therefore, stress, not pitch, is marked in the Brokskat list. In the Brokskat list, palatalization is marked with [j]; the alveolar affricate is accordingly transcribed [dž], whereas in other Shina dialects it is transcribed /j/ (džan'gal instead of jangál 'forest'). The Kashmiri word list is near-phonemic; the Kashtawari, Poguli and Siraji lists less so. Of these latter four languages, only Kashtawari shows unambiguous evidence of pitch contours, with a schleifton occurring in words of which a historical voiced aspirated initial consonant has become devoiced and deaspirated (Kishtawari pǒ'y 'brother'; cf. Kashmiri, bo:y 'brother' < bhrátr-). A rising tone was occasionally heard in Siraji words, and is marked with an acute accent.

4 The phonological system of Gilgiti Shina is documented in Radloff 1999 and Degener 2008 (pp. 13-15); the phonological system of Kohistani Shina is documented in Schmidt and Kohistani 1998 and Schmidt and Kohistani 2008 (pp. 15-39). We found that these analyses worked quite well for all the dialects transcribed except for Brokskat. Phonological differences between the dialects are discussed in $\$ 3$ of this article.

5 Every Shina word contains one accented syllable. In short syllables, the accent is realized as a high pitch and is shown as an acute accent over the vowel (ázo 'rain'). The accent need not be written on short monosyllables. Long syllables, written with double vowels, normally carry the word accent. Except in Brokskat, long vowels may have a high falling pitch, shown as an acute accent on the first vowel, or mora (táaro 'star'); or a low rising pitch, shown as an acute accent on the second vowel or mora ( $b a a ́ l$ 'child'). Unaccented long vowels have been documented for Kohistani, but not for the remaining dialects. 


\section{Overview of cognates}

Table 1 (pp. 237-8) provides a snapshot of some lexical variations in these ten speeches. It shows that Shina and Kashmiri do not share a large number of cognates even in a selective list, and that where they do occur, their phonological developments have been strikingly different.

Siraji, classified by Turner as Western Pahärīi, is no close relative of Kashmiri, although items $1 \mathrm{~b}, 2 \mathrm{~b}, 5,17,20 \mathrm{~b}, 24 \mathrm{~b}$ and $25 \mathrm{a}$ group it with Kashmiri. Items 3, 8, 9, 10, 11, 14a, 21 and 22 on the other hand group it with Shina. Only Kishtawari and Poguli have a claim to be true dialects of Kashmiri, although a glance at the lists will find many differences between Poguli and Kashmiri. The overall unity of the Shina dialects does not exist in the "Kashmiri" sample.

Items no. 6a, 10 and 12 show Kashmiri and Poguli $h$ corresponding to OIA $s, s$ (and Shina $s$ ). The Kashtawari cognates show this feature only in item no. 12. Siraji does not share this innovation. The schleifton in Kashtawari is unique to that dialect, and there are many examples of it in the Kashtawari word list. A shorter and shallower version of this tone also occurs with short vowels, and is marked in the same way.

The processes which gave rise to the cerebral consonants $c$ and $z$ (j) in Shina have little counterpart in Kashmiri; compare nos. 13, 15, 19, 21 and 25a. However, nos. 17 and 20a show OIA $k s s>$ Kashmiri $c^{h}$, when occurring in final position.

Table 1 also shows certain features of Kashmiri which are unique in NIA languages: a set of central vowels: / $i$ in $\partial$ o:/ and palatalized consonants. In Poguli items, the central vowels are transcribed phonetically. Brokskat has also developed central vowels, as discussed below.

Kashmiri is a syllable-timed language, and stress is not phonemic. It is however marked in the Kashmiri word lists when non-initial. Kashtawari and Poguli also appear to be syllable-timed; however we cannot make a definitive statement about this.

The folk tradition of the Brokskat speakers, recorded by Francke (1977: 67-73), says that their ancestors migrated to Ladakh from Gilgit. Items no. 2a, 4, 11, 14, and 18 show that Brokskat shares 
phonological developments with Gilgiti, rather than with the closer Drasi dialect, although it has converged so much with the Purik dialect of Tibetan that it is no longer intelligible to speakers of any other Shina dialect.

Items no. 2a, 4 and 11 group Kohistani, Guresi, Astori and Drasi. Kohistani falls on the Gilgiti side in items no. 5 and 7. The Guresi, Astori and Drasi dialects preserve the largest inventory of final consonant clusters, which is an archaic feature. They also possess initial consonant clusters; however, except in the case of nos. 22 and (possibly) 4, these are secondary developments, due to metathesis (Morgenstierne 1947: 152-154) or vowel contraction (no. 23).

The main focus in this paper lies on the dialects of Shina in an areal, rather than historical, context. ${ }^{6}$ Shina, while itself fairly homogeneous, is spoken in a linguistic environment of striking diversity, ranging from dialects of Tibetan in the east, to Kashmiri in the south, Burushaski in the north, and Pashto and Indus Kohistani in the west. Moreover, Persian has been influential as an administrative language in the old Kashmir State. We wish to describe the resulting contact phenomena in Shina, and to identify the sources. We shall begin with phonological and lexical data, based on the lists themselves, and then bring in a few of the more salient grammatical features. To our colleagues working with Kashmiri, who wish for an equally detailed treatment of Kashmiri, we extend an invitation to them to use our Kashmiri data in a similar study.

\section{Phonology}

\subsection{Initial clusters with consonant $+r$ :}

As is well known, the OIA $C+r$ clusters disappear in Shina; $t r>c$; $d r, b h r>z, k r>k ; p r>p$. This describes the western dialects; however some eastern dialects retain some word-initial $C+r$ clusters (some possibly original but most the result of metathesis of $r$ ):

6 See Schmidt 2004 for a more historically oriented approach. 
Table 1: Comparative lexical items in six dialects of Shina and four related to Kashmiri

In Shina, $\dot{V}$ shows the accent. In Kashomini, $\hat{V}=$ a rising tone; $\breve{v}=$ a low rising tone.

\begin{tabular}{|c|c|c|c|c|c|c|c|c|c|c|c|}
\hline OIA & $\underline{\text { Gilgiti }}$ & $\underline{\text { Koh. }}$ & $\underline{\text { Guresi }}$ & Astori & $\underline{\text { Drasi }}$ & Brok. & $\underline{\text { Kash. }}$ & $\underline{\text { Kisht. }}$ & $\underline{\text { Poguli }}$ & $\underline{\text { Siraii }}$ & \\
\hline 1a. áśva- & ãšso & ášpoo & ăšip & ấšip & ấšup & aavš & - & - & - & - & 'horse' \\
\hline 1b. ghōta- & - & - & - & - & - & - & gur & kŏṛ & $\mathrm{g}^{\mathrm{h}} \mathrm{rr}$ & $\mathrm{g}^{\mathrm{h}} \mathrm{o}:$ 'ṛo & 'horse' \\
\hline 2a. gōṣṭá- & goót & góoș & góoș & góoṣ & góoș & goot & - & - & - & - & 'house' \\
\hline 2b. ghara- & - & - & - & - & - & - & gari & kări & gor & gar & 'house' \\
\hline 3. hásta- & hat & hat & hat & hat & hat & hat & athì & athi & a:ht & hat & 'hand' \\
\hline 4. *drișți- & diț & diș & drișți & dișț & dișt & dit & - & - & - & - & 'handspan' \\
\hline 5. așțá & ãș & ãș & ãșt & ãș & ãșț & aș & ə:t & extrth & $a \cdot h t ̦$ & $a t^{\mathrm{h}}$ & 'eight' \\
\hline 6a. krsṣnáá- & kíno & kíno & kíṇu & kíṇo & kíno & 'kyono & 'kruhun & 'krišun & 'kribnu & - & 'black' \\
\hline 6b. kāla- & - & - & - & - & - & - & - & - & - & ka:'lo: & 'black' \\
\hline 7. kárman- & kom & kom & krom & krom & krom & krom & kərm & - & - & 'kammə & 'work' \\
\hline 8. f̊́kșa- & icc & ic̣h & iç & ic̣ & iș & - & - & - & - & ich & 'bear' \\
\hline 9. mūṣa- & mưúzi & muúzo & mứjụu & muúji & muúzịi & 'm\#tzi & - & - & - & muš̌ñ̃̃: & 'mouse' \\
\hline 10. suna- & šũ & šũ̃u & šúũũ & sú̃ũ & sũ̃ ũ & šwaa & hum & un & hun & šũ'ṭ̣a: & 'dog' \\
\hline 11. taptá- & taáto & táto & tátu & tátto & tátto & 'taato & tot & tot & - & tat'to: & 'hot' \\
\hline 12. şrñnga- & șíno & șígo & șínu & șin & šíjo & šin & hey & hin & hing & šingə & 'horn' \\
\hline 13. bhūrja- & jốōẓia ${ }^{1}$ & jóoẓi & jóoẓi & jốõẓi & jóozí & 'z̧oẓi & burzu kul & $1-$ & - & - & 'birch' \\
\hline 14a. haridra- & halíjo & - & - & - & - & hal' dzuro & jodur & ljodur & lidru & hal'dro & 'yellow' \\
\hline 14b. pïtala- & - & píilo & píilu & - & - & - & - & - & - & - & 'yellow' \\
\hline
\end{tabular}

1 Means 'pine tree'. 
Table 1: Comparative lexical items in six dialects of Shina and four related to Kashmiri

In Shina, $\hat{V}$ shows the accent. In Kashmiri, $\hat{v}=$ a rising tone; $\check{V}=$ a low rising tone.

\begin{tabular}{|c|c|c|c|c|c|c|c|c|c|c|c|}
\hline OIA & Gilgiti & $\underline{\text { Koh. }}$. & Guresi & Astori & $\underline{\text { Drasi }}$ & Brok. & $\underline{\text { Kash. }}$ & $\underline{\text { Kisht. }}$ & $\underline{\text { Poguli }}$ & $\underline{\text { Siraji }}$ & \\
\hline 14c.gaurá- & - & - & - & - & gúuro & - & - & - & - & - & 'yellow' \\
\hline 15. kṣétra- & çhéeç & - & çhéeç & $\begin{array}{l}\text { çhéec, } \\
\text { khái }\end{array}$ & çhéess & kheey & $\mathrm{k}^{\mathrm{h}} \mathrm{ah}$ & - & - & - & 'field' \\
\hline 16a. cakrá- & cárko & - & cáku² & caáko & cáko & $\mathrm{caq}$ & - & - & - & - & $\left\{{ }^{c}\right.$ spinning $\}$ \\
\hline 16b. yantrá- & yốr ${ }^{3}$ & yốōṣ & yũș & no data & no data & no data & yãndir & yãndir & yandiri & džãn'tar & $\{$ wheel'\} \\
\hline 17. ákși- & açhíi & açhíi & açhíi & açhîi & açhíi & a'çhii & $\partial c^{h}$ & $\partial^{h^{j j}}$ & aš & $\operatorname{ach}^{\mathrm{j}}$ & 'eye' \\
\hline 18. phalá-? & phalaá & paloó & paloó & paloó & paloó & pa'laa & - & - & - & - & 'apple' \\
\hline 19. bhrắtr- & záa & z̧áa & jáa & záa & záa & 'baayo & bory & pǒxy & ba:run & bráu & 'brother' \\
\hline 20a. kákșa- & kaç & kaç & kaç & no data & kaș & - & $\mathrm{kac}^{\mathrm{h}}$ & - & - & 一 & 'grass' \\
\hline 20b. ghāsá- & - & - & - & - & - & gaas & gassi & kăssi & g3:as & $g^{\text {háss }}$ & 'grass' \\
\hline 21. *jāmātra- & jamaçoó & jamçó & jaməçoó & jamaçoó & jamaçoó & ža'moo & zarmatur & za'motur & zamotru & džama'tro: & 'son-in-law \\
\hline 22. *prișu- & pî̃jọo & píizo & príịo & príizu & príizo & 'puzo & $\mathrm{p}^{\mathfrak{j}} \mathrm{ušs}$ & $\mathrm{p}^{\mathrm{j} u \check{u}}$ & $\mathrm{p}^{\mathrm{j} u h}$ & pri:'šu: & 'flea' \\
\hline 23. purāṇá- & próoṇo & póoṇo & próoṇu & no data & no data & no data & proin & no data & no data & no data & 'old' \\
\hline 24a. āṇdá- & haṇeé & haṇó & haṇõố & - & - & - & - & - & - & 一 & 'egg' \\
\hline 24b. sthūlá- & - & - & thuuúl & thhuúl & thhuúl & țhul & thusl & țhu:l & tho:l & țhú:l & 'egg' \\
\hline 25a. tráyah & çée & cée & çe & çée & cée & - & tre & tre & - & trei & 'three' \\
\hline 25b. trāyah & - & - & - & - & - & traa & - & - & caii & - & 'three' \\
\hline
\end{tabular}

2 Means 'spindle'.

3 Means 'water mill' in Gilgiti and Kohistani. 
Ex. 1a: $C+r$ clusters in word-initial position

OIA *prișu- 'flea': Gil. pự̃jo. Koh. píizo, but Gur. príịo, As. príizu, Dr. príizo

OIA diști-, *driști- 'hand span’: Gil. dit, Koh. diș, but Gur. driștit

OIA kárman- 'work': Gil. Koh. kom, but Gur. As./Dr. krom $(<* k r a(m) m a-)^{1}$

But: OIA dïrghá 'long': Gil. Gur. jígo, Koh. As. zígo, Dr. jíno

(The normal development of $d r$ would be z. zigo 'long' < dìrgháwith metathesis. ${ }^{2}$ Turner gives two different etyma for 'hand span', of which the first lacks the $d r$-cluster.) There are many more examples; these are merely those we have documented best. There are also some riddles which we cannot solve, such as the existence of some bilabial stops with $r$ - in Gilgiti: prik 'jump', ${ }^{3}$ próono 'old' (compare Kohistani póono); brî́W 'rice paddy' (compare Kohistani by $\tilde{u})$. But by and large the eastern dialects appear to be more influenced by Kashmiri, which does retain word initial $C+r$ clusters $^{4}$ (compare Kashmiri tre with Shina cée 'three'). Such clusters appear to be limited in Shina to $p r-, b r-, d r$ - and $k r$-. Only Brokskat has a $t r$ cluster: traa 'three', trobeš 'thirteen'. However these items are unique in the Brokskat sample, and most other items show the expected

1 Morgenstierne 1947: 10. Metathesis of both anteconsonantal and postconsonantal $r$ is common in Dardic, and the tendency is attested as early as Aśoka's Kharoshthi inscriptions, and must have preceded the loss of $r$, in fact the regular development of $t r>c, d r>z$ et cetera testifies to the development of initial $C+r$ clusters through metathesis. However there is no scope for a discussion of this in this paper.

2 In Palula, an archaic dialect of Shina which must have separated from the other dialects before the mid-seventeenth century (Cacopardo and Cacopardo 2001: 88), not all of these changes have yet taken place: dhrigu 'long', bhroo 'brother' (Liljegren 2008: 131, 69). Nevertheless, Palula already has the retracted fricatives: dhraáç 'grape', zamí 'sister's husband' (Liljegren 2008: $60)$.

3 prik is shared with Burushaski and is probably borrowed from that language. It is not listed in Turner.

4 Koul 2007: 902-3. 
development (Brokskat 'cyya 'cold'; cf. Guresi, Astori caû́u $<$ ? trāsa-).

Ex. 1b. Brokskat items

traa 'three'

trobeš 'thirteen'

But: 'cyya 'cold' < ? trāsa-

And: 'çito 'titito 'bitter' ( $<$ trssțáa $)$

Besides the expected 'citto 'bitter' ( $<$ trștáa), Brokskat also has 'tito; compare Kashmiri teț 'bitter'. Guresi has a tr-cluster in tráam 'copper' (< tāmrá); cf. Kashmiri tra:m 'copper'. Guresi does show the expected development in çakyoónu 'to look at' (< tarkáyati). The occurrence of word initial $C+r$ clusters probably reflects contact with Kashmiri, even if these are sometimes borrowings, and not the retention of old OIA clusters.

\section{Ex. 1c. Guresi items}

$$
\text { tráam 'copper' (< tāmrá-) }
$$

But: çakyoónu 'to look at' (< tarkáyati)

\subsection{Central vowels}

As is well-known, Kashmiri has central vowels, both long and short

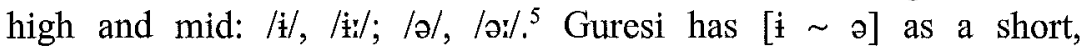
unstressed allophone of $/ a /$, and while it is not a phoneme, this vowel is among other things the masculine plural gender suffix, so that it occurs frequently. In Example 2, it is transcribed phonetically.

\section{Ex. 2: Guresi schwa}

phû́ũüi 'moustache' (cf. Gilgiti phúne)

úpi 'sickle' (cf. Drasi óono)

jaanəwáar 'bird'

ấšip ‘horse' (cf. Gilgiti ášpo) 
The outlying Ladakhi Shina dialect Brokskat of Garkon has developed the central vowels $[\mathfrak{k}]$ and [3] (see example $3 \mathrm{a}$ ), but their origin is uncertain, because Garkon lies at a considerable distance from Kashmir, and the overwhelming influence on Brokskat is from Purik, which is a dialect of Tibetan. ${ }^{6}$ To complicate the picture, the Brokskat back vowels [u] and [o] have unrounded variants [ur] and [y], and we are unable to isolate the determining factor(s). For [a] and [3] the sample provides a minimal pair: byss 'man, byaa 'hen'.

\section{Ex. 3a: Brokskat central and unrounded back vowels}

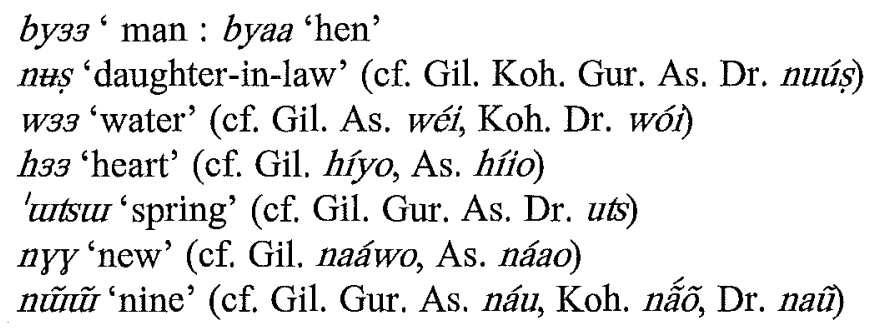

Schmidt and Koul (1984: 18), reporting on the original Shina-Kashmiri project, wrote that Kashmiri, Poguli and Kashtawari have developed both central vowels [i vowels [u y]. The appearance of these vowels in Brokskat may be an areal feature, rather than a specific contact feature. According to Marius Zemp (2008: p.c.), there is a tendency in Purik to centralize the vowels / $\mathrm{u} /$ and /a/ that is most clearly audible in an alveo-palatal environment. Bielmeier finds the sounds [o] and $[\mathrm{H}]$ in the closelyrelated Balti dialect, but as allophones of $/ \mathrm{a} /$ and $/ \mathrm{u} / \mathrm{in}$ restricted environments. ${ }^{7}$ Rangan (1979: 16) shows the vowel $[\Lambda]$ as a short allophone of $/ \mathrm{a} /$, and this is also true of all the Shina dialects; however we recorded the quality of Brokskat /3/ as slightly lower and backer than $[\Lambda]$.

Developments within Shina itself may account for the unrounded back vowels, as Schmidt and Kohistani (2008: 17-18) show

6 Ramaswami 1975: 64, 1982: 7 does not mention these vowels.

$7 \mathrm{c} / \mathrm{a} / \mathrm{wird}$ nach postkonsonantischem /j/ gehoben und zentralisiert $\mathrm{zu}$ [ə]. Diese Palatalisierung tritt aber nicht ein, wenn dem Vokal $/ \dot{\mathrm{n}} /$ folgt.../u/ vor $/ 1 /$ wird palatalisiert $\mathrm{zu}[\mathrm{u}]$ (nicht aber vor $/ \mathrm{r} /, / \mathrm{m} /, / \mathrm{n} /$ oder $/ \dot{\mathrm{n}} / \ldots$.. Bielmeier (1985: 65). 
unrounded allophones of $/ \mathrm{u} /$ and $/ \mathrm{o} /$ as a result of regressive vowel assimilation across syllable boundaries. The same phenomenon can be found in Guresi and Drasi. The conditioning factor appears to have been mostly lost in Brokskat, however:

Ex. 3b. Possible conditioning factor for Brokskat unrounded vowels

'p yуçi 'granddaughter'. Cf. Gil. Koh. As. Dr. póoçi 'pooço 'grandson'. Cf. Gil. Koh. As. Dr. póoço

\subsection{Miscellaneous Guresi features}

Guresi shows Kashmiri influence in a few other ways. It has a bilabial fricative in initial and intervocalic positions, while other dialects have a back vowel glide ( $v$ instead of $w$ ). Compare Gur. vói 'water' to wéi, wó $i$ in the other dialects.

Retraction of $s, c$ is rather weak in Guresi. Kashmiri does not have these sounds.

\subsection{Voiced aspirates in Kohistani}

The OIA voiced aspirated consonants have been lost in the majority of Dardic languages, as is quite clear from the vocabulary in Table 1. However voiced aspirates do occur in the Kohistani dialect of Shina, and there are minimal pairs for some of them. ${ }^{8}$ A comparison with various dialects of Indus Kohistani ${ }^{9}$ has turned up cognates with voiced aspirates for most such items, suggesting that the feature has come back into Kohistani Shina through borrowing from the languages spoken across the Indus.

8 Schmidt and Kohistani 2008: 30-31.

9 Sources: Zoller 2005, Razwal Kohistani 2007, p.c. 


\section{Ex. 4. Voiced aspirates in Kohistani}

ghaṇá 'item held in trust'. Patani gha'ṇa $(<$ gráhaṇa- with leftshift of aspiration)

dhaará 'robbery'. Patani dhar'ṛa; Bhatīsē dhāràh 'cattle raid' $(<$ chhattī $)$

jharı' 'heavy rain'. Patani jha'rit; Gabār Žharéy 'continuous rain' ( $<$ jhadì). Cf. Gil. jarí, Gur. jarí.

bhaaráa 'cash payment'. Patani bhar'tar, Indus Koh. bhārà ${ }^{h}$ 'wage for laborers; bribe' ( $<$ *bhārta-)

bhaák 'bull' (no cognates) $(<$ *bhakkha-)

Most words with voiced aspirates do not have cognates in other Shina dialects. jharí 'heavy rain' has cognates in Gilgiti and Guresi, however without the aspiration.

\section{Implications of loanwords}

Loanwords are relatively few in these lists of core vocabulary, but those which do occur point to different sources. In example 5, we show for the most part only those words the source of which we can confirm with reasonable certainty. ${ }^{10}$ In some cases, a question mark is shown before an item: this indicates that we think we have identified the source of a loanword, but could not confirm it positively. Radloff (1992: 136, 139) provides a list of vocabulary shared by Shina and Burushaski, but does not attempt to identify the source language.

Approximately 31 per cent of the Brokskat vocabulary in our sample is not of Indo-Aryan origin. Much of this appears to be borrowed from Purik - a Tibetan language - while 11 of the IndoAryan words are borrowings from Kashmiri or other unidentified Indo-Aryan language(s), and are not Shina. There are also a few

10 The references consulted were: Burushaski: Berger 1974, Lorimer 1935, Willson 1999; Kashmiri: Tickoo 2006; Purik/Balti: Bailey 1975, Sprigg 2002, Rangan 1979, Bielmeier 1985; Pashto: Raverty 1980; Indus Kohistani: Zoller 2005; general: Fussman 1972, Degener 2008. 
Purik loanwords in Drasi. The resources to check Purik vocabulary are however very inadequate. ${ }^{11}$

Example 5: Loanwords in the word lists

\section{Gilgiti}

From Burushaski : chhî́s 'mountain', chúmu 'fish', tharíni 'churn', bári 'field', hésko 'loom', táši 'roof', bisáaç 'sickle', pajúu 'salt', ${ }^{12}$ bur(gaál) 'cloud', birdí 'earth', jakún 'ass', ?(harâ) cịn 'sparrow', ${ }^{13}$ dudữúyo 'bumblebee', búuši 'cat', ${ }^{14}$ phurguú 'feather', ${ }^{15}$ karkáamuš 'hen', karéelo 'ram', jaroóti 'apricot', tom 'tree', zamoók 'to beat', thar (doók) 'to fly', șak 'full', tušáar 'many', bidíriko 'round', hameci 'cheese'

From Persian: ${ }^{16}$ šáam 'evening', hazáar 'thousand', dušman 'enemy', parí 'fairy', eéno 'mirror', šarm 'shame'

From Kashmiri: bat 'rice'17

11 For Purik itself there is Bailey 1975 (a word list) and, Rangan 1979. Sprigg 2002 and Bielmeier 1985 (for Balti) were also consulted.

12 Radloff (1992: 135) considers this a loan word from Balti, however (Zeisler (p.c., 4 June 2008) wonders whether this is a true Balti (Tibetan) word and not a loan. "In Balti, the Tibetan word is tsha." See also Bailey (1975: 41), who reports the Purik word for salt as tshä. Degener (2008: 291) points to Burushaski bayú 'salt'.

13 Turner 1966 provides no Indo-Aryan etymology for this word. The segment çị however may be borrowed from Burushaski çen 'bird' (Berger 1974: 140) with assimilation of the final vowel to a retroflex point of articulation.

14 Degener 2008: 253 points to Burushaski bus' 'cat'. See also Fussman 2: 10508 . This word must have been originally borrowed by Burushaski from Shina, but it has apparently been borrowed back into Gilgiti, as the other dialects show forms in p-: puši, piši, pišlu.

15 Lorimer 1935: 293 gives Burushaski pfulgo, fulru; Berger 1974 gives pholro; the match is not exact, but we can find no Indo-Aryan etymology for this word.

16 It is impossible in most cases to ascertain whether borrowings from Persian have come directly from Persian, which for some centuries was the administrative language of Kashmir State, or more recently via Hindi-Urdu. If the loanword is originally Persian, it is identified as a borrowing from Persian.

17 Buddruss (1983: p.c.), without then knowing about Astori baát 'rice', identified Gilgiti bat 'rice' as a Kashmiri loan because the regular development of bhaktá- would be bhatta > baát. In other words, $V \bar{V}$ (accent on the second mora) in most cases results from secondary lengthening following the 
(Gilgiti)

From Pashto: tumák 'gun'

\section{Kohistani}

From Burushaski: chúbo 'fish', phúu 'fire', jakuín 'ass', zarootọo 'apricot', cherís 'root', tom 'tree', thor (doón) 'to fly', básko 'all', tušáar 'eating to satisfaction', burús 'cheese'

From Pashto: mágaz 'brain' (Pers.?), kóoț 'village', asmán 'sky', nur xáataa 'east', qablá 'west', zir 'thousand', ux 'camel', dušman 'enemy', ${ }^{18}$ Šaram 'shame', zhanzhír, 'chain'(Pers.?), tubák 'gun', larám 'scorpion'

From Indus Kohistani: dóoli ' field', ${ }^{19}$ cágar 'spinning wheel', ${ }^{20}$ talúun 'rice paddy', bhoráa 'bumblebee'

From Persian: péeši 'afternoon'

\section{Guresi}

From Burushaski: çhîiṣ 'mountain', pfúu 'fire', burús 'curds', jakún 'ass', jaroótu 'apricot', cheríṣ 'root', tom 'tree', básko 'all', șak 'full', tišáar 'many'

From Kashmiri: káco 'armpit', mámu 'breast', khat 'bed', váan 'loom', trat 'lightning', bunílu 'earthquake', thuúl 'egg', delú 'bark of tree', daș 'grape(s), ${ }^{21}$ tráam 'copper'

reduction of ancient consonant clusters. Ex.: lavitra- $>$ letra $>$ leéç 'sickle', taptá- > tatta > taáto 'hot'. OIA $\bar{V}$ (a long vowel) results in $V$ (accent on the first mora): bhrắtro $>$ záa.

18 dušman and Šaram could hypothetically have been borrowed from either Persian or Pashto; but since Indus Kohistan was never a part of the Kashmir State and was not exposed to Persian as an administrative language, we assume that these items have been borrowed from Pashto, which is a second language for many speakers of Kohistani Shina.

19 Indus Kohistani has dộl' field'; Zoller 2005: 225 points to Kashmiri dọr 'land covered with very shallow water' and West Pahari dortu 'small field'. This study also collected Kashmiri dal 'field. There are thus many sources for the Kohistani Shina word; of these, Indus Kohistani lies in closest proximity.

20 Zoller 2005: 159 gives Indus Kohistani cìgAr 'spinning wheel; loom'; one would expect Kohistani Shina to have preserved the initial consonant in the loan, however it may have been contaminated by $c$ - in Shina cárko, caáko, cáku (all 'spinning wheel'). 
(Guresi)

From Persian: maġzii 'brain', tîir 'arrow', mašrik 'east', péešin 'afternoon', šăam 'evening', magrib 'west', zamíin 'earth', jaanəwáar 'bird', dušman 'enemy'

From Pashto: tumák, tubák 'gun'

From Balti: zams 'copper'

\section{Astori}

The Astori speaker who supplied our list had married into a Burushaski-speaking family; therefore a list of Burushaski loan words in her list might not reflect the Astori dialect. For example, Radloff (1992: 135) reports that Astori does not use the word pajúu 'salt' but uses the same word as the Diamer and Kohistan clusters (luúni). Our Astori speaker uses pajúu. Loanwords from other dialects are noted here.

From Kashmiri: mam 'breast', ${ }^{22}$ khat 'bed', khái 'field', thuúl 'egg', tiiri 'feather'

From Persian: bel 'mattock', zilzilá 'earthquake', jangál 'forest', dušman 'enemy', šiišá 'mirror'

From Pashto: tumák 'gun'

Drasi

From Burushaski: phúu 'fire', chímo 'fish', zakún 'ass', karéelo 'ram'

From Kashmiri: mámế 'breast(s)', palán, caarpái 'bed'; gẫăm 'village', thuúl 'egg', daș 'grape(s)',

From Persian: šáam 'evening', jangál 'forest' (Urdu?), injîir 'fig' (Urdu?), dušman 'enemy', šiišá 'mirror'

21 The Kashmiri word is $d a c^{h}$, the Shina word is jaç zac; Guresi das has borrowed the first consonant and vowel of the Kashmiri word, but retained the retraction in the final consonant.

22 mam and its variants (mámu, mamế) are shown as loanwords from Kashmiri, because the Gilgiti and Kohistani dialects show a different word: cucu, cíci (T. 4855). However it could be just as well borrowed from Burushaski, and could be considered one of the isoglosses separating the western dialects of Shina from the eastern ones. 
(Drasi)

From Purik: gurgúr 'churn', ? thokteé 'mattock', tsangúl 'earthquake', ? ša (bóko) 'good', kirkíro 'round', ${ }^{23}$ tsat 'fever'

From Pashto: tumák 'gun'

\section{Brokskat}

As mentioned, much of the non-Indo-Aryan vocabulary in Brokskat appears to be borrowed from Purik. There are however few published sources for Purik vocabulary (mainly Bailey 1975 and Rangan 1979), necessitating recourse to the neighbouring dialect Balti (Sprigg 2002). With better data for Purik, we might have traced additional loanwords.

From Burushaski: tharini 'churn', pa'ye\# 'salt'

From Kashmiri: ?kh\#n 'elbow', car'pii 'bed', džan'gal 'forest', kxar 'ass', ${ }^{24}$ thul 'egg', 'tiito 'bitter'

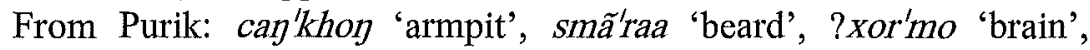
?kxal'ma 'kidney', sam'dal 'moustache', žin'gat 'neck', stod 'shoulder', daah 'arrow', thal'tsir 'ashes', g'ãã'tsi 'honey', thak'șaa 'loom', ?thok'tse 'mattock', so'džen 'milk', brok 'lightning', ${ }^{25}$ char'ch\# 'rain', šar 'east', grib 'shady side of mountain', $n^{j} u b$ 'west', lo'kyr 'year', tsay'gul 'earthquake', ḍen'mo 'bear', zo, lay'to 'bull', sok'paa 'feather', nyãã 'fish', byaa mo 'hen', byaa pho 'rooster', chuir'di 'ram', chah 'maize', laq'tshuks 'tree', cay'ma 'willow', ?škela'ris 'to swim', cuk 'all', žar'baa 'blind', $h$ iin 'left (direction)', tray wu'ji 'right (direction)', 'titaq 'small', 'stoy 'thousand'

23 According to Claus Peter Zoller (p.c.), this word is also found in Western Pahari; but Purik kirkir 'round' (Rangan 1979: 37) seems a more immediate source (although the word may be a loan in Purik as well). Most Shina dialects (including Brokskat) have diduúro dududuúru.

24 car'pii 'bed' džan'gal 'forest' and kxar 'ass' might have been listed as loans from an unidentified Indo-Aryan language, or in the case of džan'gal and kxar, from Persian; however as these words occur in Kashmiri, this would seem to be the more immediate source.

25 The semantics of this loan are not quite straightforward, as Purik brǔk means 'thunder' (Bailey 1975: 43); Claus Peter Zoller (p.c.) points to possible influence through the widespread baraq 'lightning' (see Fussman 1972, 45 éclait). 


\section{(Brokskat)}

From unidentified Indo-Aryan language(s): 'guli 'finger', 'baayo 'brother', kheey 'field', bi 'Itut 'cat', 'sææno 'small'

\section{Grammatical features}

\subsection{The agent case marker in $s V \sim-s \sim-e s$}

The Guresi, Drasi and Kohistani dialects have two agent cases, one marking subjects of imperfective transitive verbs $(s V \sim-s \sim-e s)$, the other marking subjects of perfective transitive verbs $(-e \sim-i,-o)$. Bailey (1924: $222 \mathrm{ff}$.) calls them Agent I and Agent II. Gilgiti has only one agent case (Agent I, or $s e \sim-s$ ) which marks the subjects of all tenses of transitive verbs. In Guresi, the two agent cases have almost completely collapsed in nouns, but are distinguished in some pronouns. ${ }^{26}$ We do not have grammatical data for Astori, but our rather sketchy data for Brokskat bear out what has been reported by Grierson (1919: 210-211) for the "Brökpā" of Dah-Hanu, that it also has two agent cases.

\section{Ex. 6 Examples of agent cases}

Agent I: $s V \sim-s \sim-e s$

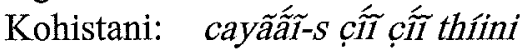
sparrow-AG1 chirp chirp does The sparrow is chirping. ${ }^{27}$

Guresi: $\quad$ jaa so mo-t kalám dáu $\quad$ (also: jaa-s) brother AG1 me-DAT pen gave Brother gave me the pen.

Gilgiti: cãấy se "ma-s maáni neé dámis" thigí bird AG1 I-AGI pearl not give she.did/said The bird said, "I won't give the pearl." 28

26 Schmidt 2004: 49-50.

27 Schmidt and Kohistani 2008: 52.

28 Radloff and Shakil 1998: 23. 
Drasi: $\quad$ aaje su kareé-ga cheeç-o nin théi nuš

mother AG1 when-also field-OBLpl. weeding does not

Mother never pulls weeds in the fields.

Agent II: $-e \sim-i,-o$

Kohistani: mĩ bubá-e mo-ṛ tak-ak atáaus

my father-AG2 I-DAT button-one had.brought

My father had brought me a button.

Guresi: $\quad$ m-ẽ̃ háti dijaryáas

I-AG2 hands I.washed

I washed my hands.

Drasi: Myô báb-e gújar-ek mazúuri deé las caryoóno cheráũ My father-AG2 Gujar-one labor giving sheep to.graze kept My father hired a Gujar to graze the goats.

Agent II is attested historically, as Buddruss (1967: 33) reports an agent case suffix in $-e$ with perfective transitive verbs in Sawi, which is an archaic dialect of Shina; ${ }^{29}$ but neither Buddruss nor Liljegren (2008) reports an agent case with imperfective transitive verbs for dialects of Sawi or Palula; thus Shina probably did not possess the agent case in $s V \sim-S \sim-e s$ at the time Palula and its cousins separated from the other dialects before the middle of the seventeenth century. The earliest mention of this suffix which we have found is in Wilson (1899), describing the Guresi dialect. It reminded Bailey (1924: 211) of the "Tibetan agent which ends in $-s$ ". Unlike all the other noun cases, it is added to the nominative stem, rather than to the oblique. It is an innovation, probably a borrowing, but from where? Schmidt and Kohistani (2008: 51) quote Zeisler (2007: p.c.) as reporting that in the lower Ladakhi varieties (Sham, western Nubra, Purik) the agent marker is $-i s$ (after a consonant) and $-s$ (after a vowel). However after subsequent research, Zeisler (2008: p.c.) finds that the $-s$ or $s V$ marker was alien to an early version of

29 In Palula, the noun takes the oblique case when serving as the agent of perfective transitive verbs; this has the form (in the singular) of a suffix in $-a$, $-i$ (Liljegren 2008: 94). 
Tibetan. ${ }^{30}$ Given however that the Shina agent case in $s V \sim-S \sim-e s$ does not appear before the seventeenth century, is apparently alien to the Indo-Aryan system, and moreover appears only with imperfective verb forms, Zeisler would preclude a borrowing from Shina into West Tibetan; while it is possible that Shina has borrowed the form from West Tibetan.

We can however be sure that it has not been borrowed by Shina from Burushaski, as in that language the agent marker is $-e$, which reminds of Shina Agent II.

\subsection{Subject-verb concord}

The verb in all these dialects agrees with the subject/agent, whether the dialect has both agent cases, or only one. This is another innovation; in Palula and Sawi a transitive verb agrees with the object (or patient) in perfective tenses. ${ }^{31}$ Here the stimulus for the innovation may indeed be Burushaski, in which the verb agrees with the subject (or agent, for which reason Lorimer [1935: 65] calls the actor-subject case the agential case). It cannot be Kashmiri, which is typically split-ergative with verb-object agreement, ${ }^{32}$ nor can it be Indus Kohistani, which is weakly split-ergative, and does not have gender or number concord between verb and either object or patient (the verb takes an absolute form). ${ }^{33}$

30. Zeisler considers the possibility that the Tibetan ergative marker is derived from the genitive marker. In more recent research she has discovered that there is no formal distinction in Burushaski and some of the Upper Ladakhi dialects between the genitive and agent markers (Berger 1974: 20-21: the same formal marker -e designates both the agent and the genitive). She adds: "Now it is also long known that the Tibetan ergative marker is derived from the genitive marker by an additional, originally syllabic morpheme *so or *su, which finds its reflection in some of the Ladakhi dialects as $/ \mathrm{si} /$, or $/ \mathrm{se} / \sim / \mathrm{ze} /$ (Classical Tibetan $\{$ kyi $\}>$ kyis $\}$."

31 Liljegren 2008: 255-6, Buddruss 1967: 51-2.

32 Koul 2007: 919.

33 Zoller 2008: p.c.: "Indus Kohistani has split ergativity with ergative constructions basically in all the past tenses except the imperfective pluperfect. No ergative constructions are used in the present and future tense. In reality, however, the situation in the past tenses is frequently quite variable ... and it 


\subsection{Suffix-noun concord in the possessive case}

In the Kohistani and Gilgiti dialects, the possessive singular case suffix is invariant, regardless of whether the possessed noun is masculine or feminine. The dialects on the fringes of the Kashmiri speech area: Guresi and Drasi, have developed possessive suffixes which inflect for gender, agreeing with the gender of the possessed noun. This probably reflects contact with Kashmiri, in which the possessive suffix also inflects to agree with the possessed noun. ${ }^{34}$

\section{Ex. 7 Examples of possessive singular cases}

Gilgiti: ${ }^{35} \quad \tilde{c}$-éy șingáay

bear-POS blackberry-bush (f.)

the bear's blackberry bush

muláay-ey nóom

girl-POS name (m.)

the girl's name

Kohistani: góoz-ee šaróon

house-POS roof (m.)

the roof of the house

góoz-ee tíki

house-POS bread (f.)

home-made bread/food

appears to me that the just-given characterization is in fact an ideal image provided by Urdu. In the ergative constructions the subject has to take on its ergative form or add an ergative suffix. As already pointed out, in many cases ergative constructions with transitive and causative verbs are, however, not obligatory but optional. This fact may either reflect a partial continuation of a pre-ergative state of grammatical development or it may have something to do with another important fact characterizing the Indus Kohistani past tenses: in most cases the verb takes on an absolute form, i.e., there is no accord in number or gender between verb and object (or verb and subject)."

34 Wali and Koul 1997: 330.

35 Source: Radloff and Shakil 1998: pp. 97, 147. Radloff analyzes the suffix as consisting of the oblique suffix (-e-) and the genitive suffix $(-y)$. In Kohistani, where the oblique suffix is $-a$, such an analysis does not work. 
Guresi: $\quad$ gooj-õ šarún

house-POS roof (m.)

the roof of the house'

gooj-ĩ bái

house-POS bread (f.)

home-made bread/food

Drasi: $\quad m-y \tilde{o}$ bábo

I-POS father

my father

bazik-i bái

evening-POS bread (f.)

evening meal

Schmidt 2004: 48 stated that the possessive suffix does not inflect in the Shina of the Tilel Valley (a more archaic dialect of Guresi). We have since found this statement to be incorrect.

Tileli: $\quad$ m-yõ góos

I-POS house (m.)

my house

bazúk-ei bái

evening-POS bread (f.)

evening meal

There is no agreement in the possessive plural suffix, which is always $-o$ or $-\tilde{o}$.

The oldest form of the possessive case appears to be -ey, Bailey (1924) reports it as -ắi (Gilgiti) and -ei (Kohistani). ${ }^{36}$ In some Kohistani speech the suffix was a diphthong 25 years ago: goozey. It looks as though this form has been reinterpreted in the Tileli dialect as the feminine form of the possessive, while the masculine form

36 Bailey 1924: 13, 211. In Palula, the genitive suffix has the forms -e, -ii (Liljegren 2008: 94-5). 
takes - $\tilde{o}$ (apart from the nasalization, like a masculine singular adjective). In the Guresi and Drasi dialects, the resemblance to adjectives is even closer.

\section{Radloff's geographical clusters of Shina}

Radloff (1992: 122-150), working with word lists from 27 Shinaspeaking locations (with the single exception of Drasi, all in Pakistan) found that these locations can be grouped in four slightly overlapping geographical dialect clusters. The members of each geographical cluster demonstrate 85 per cent or above lexical similarity with each other. In contrast, similarity with non-cluster locations is generally less than 80 per cent. These clusters were named the Northern, Eastern, Diamer ${ }^{37}$ and Kohistan clusters. The Northern cluster is centered on Gilgit; Astori and Drasi belong to the Eastern cluster, and Kohistani belongs to the Kohistan cluster. Our corpus contains no data from members of the Diamer cluster, which is centered on Chilas. ${ }^{38}$

To what extent do the dialects we studied fit into Radloff's geographical clusters? To begin with, we found more similarity between Gilgiti and Kohistani than Radloff does ( 77 per cent versus her 63 per cent). This is probably explained by differences in the type of vocabulary we collected. Even so, Gilgiti and Kohistani clearly belong to different clusters.

If we compare our Astori and Drasi samples to each other, they have only 75 per cent ${ }^{39}$ similarity, and therefore do not fall into one cluster as Radloff places them. They are situated geographically distant from each other, separated by the 12,000-13,000 foot Deosai Plateau, and are not connected by historical trade routes.

Guresi has 81 per cent similarity with Astori (despite the fact that they now lie on opposite sides of the cease fire line between Pakistan and India). Moreover, Guresi has 83 per cent similarity with Kohistani, close to Radloff's threshold of 85 per cent lexical

37 Diamer is the district of which Chilas is the district capital.

38 It comprises Chilasi and the dialects of Tangir-Darel, Sazin and Harban.

39 Versus Radloff's 89 percent similarity. 
similarity. ${ }^{40}$ Kohistani and Astori on the other hand, are not so close, with only 74 per cent lexical similarity. These figures suggest that Guresi forms a link between Astori and Kohistani. Its geographical situation (north of the Kashmir valley in the Kishenganga/Neelum valley along the old route from Abbottabad to Astor via Srinagar and the Burzil pass ${ }^{41}$ suggest that if Guresi were included in Radloff's calculations, both Kohistani and Guresi might fall into a Southern cluster, lacking any geographic center, but with Kashmir as a central location on its line of communication.

This does not explain how communication might have taken place between Gures and Kohistan, which even in modern times is isolated from the rest of Pakistan in side valleys of the Indus. We may prefer to explain the connection by the Kohistani oral tradition which says that the Darma lineages of Chilas and Kohistan have migrated from Gures; ${ }^{42}$ however supporting evidence could come only from a historical-linguistic analysis which would lie outside the scope of this paper.

Radloff's geographical clusters are useful as descriptive categories for summarizing language contact. While all the Shina dialects have some residue of Burushaski vocabulary, attesting to ancient contact between these two languages, Burushaski loanwords predominate in the Northern cluster, whereas in the Eastern cluster and in Guresi, Kashmiri loanwords become more common. Only in the Kohistan cluster do we see any great number of loans from Pashto and Indus Kohistani, bringing with them traces in the phonology.

Burushaski has influenced not only the Shina lexicon, but also its grammar; however this influence is difficult to demonstrate. The influence of Kashmiri on both the lexicon and the grammar is on the other hand quite transparent.

To conclude, what surprises us is that the various Shina dialects still have so much in common. With dialects spoken at distances of hundreds of kilometers apart, separated by great mountain ranges, a

40 Informal mutual intelligibility tests of Guresi and Kohistani in 1989 also show that speakers of these dialects have little difficulty understanding each other.

41 Drew 1980: 395, 528.

42 Schmidt and Kohistani 2008: 3. 
high plateau and mighty rivers, we might have expected even more diversity than we see here.

\section{Abbreviations}

$\begin{array}{llll}\text { AG1 } & \text { Agent I } & \text { Gur. } & \text { Guresi } \\ \text { AG2 } & \text { Agent II } & \text { Koh. } & \text { Kohistani } \\ \text { As } & \text { Astori } & \text { NIA } & \text { New Indo-Aryan } \\ \text { DAT } & \text { Dative } & \text { OIA } & \text { Old Indo-Aryan } \\ \text { Dr. } & \text { Drasi } & \text { Pers. } & \text { Persian } \\ \text { Gil. } & \text { Gilgiti } & \text { POS } & \text { Possessive }\end{array}$

\section{References}

Bailey, T. Grahame 1975, "Introduction to Purik," in Bailey, T.G., Linguistic Studies from the Himalayas, being Studies in the Grammar of Fifteen Himalayan Dialects, 1-45. New Delhi: Asian Publication Services. First published London, 1915.

- 1924, Grammar of the Shina Language. London: The Royal Asiatic Society.

Bielmeier, Roland 1985, Das Märchen vom Prinzen Čobzan். Eine tibetische Erzählung aus Baltistan. Text, Übersetzung, Grammatik und westtibetisch vergleichendes Glossar. Sankt Augustin: VGHWissenschaftsverlag.

Berger, Hermann 1974, Das Yasin-Burushaski (Werchikwar). Grammatik, Texte, Wörterbuch. Wiesbaden: Harrassowitz.

Buddruss, Georg 1967, Die Sprache von Sau in Ostafghanistan. Beiträge zur Kenntnis des dardischen Phalūra. Munich: Münchner Studien zur Sprachwissenschaft, Beiheft M.

Cacopardo, Alberto M. and Augusto S. Cacopardo 2001, Gates of Peristan. History, Religion and Society in the Hindu Kush. Rome: Istituto Italiano per l'Africa e l'Oriente.

Degener, Almuth 2008, Shina-Texte aus Gilgit (Nord-Pakistan). Beiträge zur Indologie 41. Wiesbaden: Harrassowitz.

Drew, Frederic 1980, The Jummoo and Kashmir Territories. A Geographic Account. Karachi: Indus Publications. First published 1875. 
Francke, A.H. 1977, A History of Ladakh. New Delhi: Sterling. First published as $A$ History of Western Tibet, London 1907.

Fussman, Gérard 1972, Atlas Linguistique des Parlers Dardes et Kafirs. Paris: École Française d'Extrême-Orient. Vol. 1, Cartes; vol. 2, Commentaire.

Grierson, G.A. 1919, Linguistic Survey of India. Vol. 8, Part 2, Indo-Aryan Family, North-Western Group. Specimens of the Dardic or Piśācha Languages (Including Kāshmīrī). Reprinted Delhi: Motilal Banarsidass, 1968.

Liljegren, Henrik 2008, Towards a grammatical description of Palula. An Indo-Aryan language of the Hindu Kush. Doctoral Thesis in Linguistics at Stockholm University, Sweden.

Lorimer, D.L.R. 1935, The Burushaski Language. Vol. 3: Vocabularies and Index. Oslo: Instituttet for Sammenlignende Kulturforskning.

Kachru, Braj B. 1973, An Introduction to Spoken Kashmiri. Part 2: Glossary. Urbana: Department of Linguistics, University of Illinois.

Koul, Omkar N. 2007, "Kashmiri," in Cardona, George and Dhanesh Jain (eds.), The Indo-Aryan Languages, pp. 895-952. London: Routledge.

Morgenstierne, Georg 1947, "Metathesis of Liquids in Dardic," in Festskrift til Professor Olaf Broch. Oslo: V.A. Avhandlinger.

Radloff, Carla 1999, Aspects of the Sound System of Gilgiti Shina. Islamabad: National Institute of Pakistan Studies, Quaid-i-Azam University and Summer Institute of Linguistics.

- 1992, "The Dialects of Shina." Peter C. Backstrom and Carla Radloff (eds.), Sociolinguistic Survey of Northern Pakistan. Vol. 2, Languages of the Northern Areas, pp. 89-203 and 301-369. Islamabad: National Institute of Pakistan Studies, Quaid-i-Azam University and Summer Institute of Linguistics.

Radloff, Carla and Shakil Ahmad Shakil 1998, Folktales in the Shina of Gilgit. Studies in the Languages of Northern Pakistan, vol. 2. Islamabad: National Institute of Pakistan Studies, Quaid-iAzam University and Summer Institute of Linguistics.

Ramaswami, N. 1982, Brokskat Grammar. Mysore: Central Institute of Indian Languages. 
- 1975, Brokskat Phonetic Reader. Mysore: Central Institute of Indian Languages.

Rangan, K. 1979, Purki Grammar. Mysore: Central Institute of Indian Languages.

Raverty, H.G. 1980, A Dictionary of the Pukhto, Pashto Language of the Afghans. Karachi: Indus Publications. First published 1860.

Schmidt, Ruth Laila 2004, "A grammatical comparison of Shina dialects," in Anju Saxena (ed.), Himalayan Languages Past and Present. Trends in Linguistics Studies and Monographs 149, pp. 33-55. Berlin: Mouton de Gruyter.

Schmidt, Ruth Laila and Razwal Kohistani 2008, A Grammar of the Shina Language of Indus Kohistan. Beiträge zur Kenntnis südasiatischer Sprachen und Literaturen 17. Wiesbaden: Harrassowitz.

— 1998, "Páalus /kostyố/ Shina Revisited". Acta Orientalia 59: 106149.

Schmidt, Ruth Laila and O.N. Koul 1983, "Dardistan revisited: an examination of the relationship between Kashmiri and Shina," in Koul, O.N. and P.E. Hook (eds.), Aspects of Kashmiri Linguistics. New Delhi: Bahri Publications, pp. 1-26.

Sprigg, R.K. 2002, Balti-English English-Balti Dictionary. London: RoutledgeCurzon.

Tickoo, Jawahir Lal 2006, Kashmiri-English Dictionary. New Delhi: Indian Institute of Language Studies.

Turner, R.L. 1966, Comparative Dictionary of the Indo-Aryan Languages. London: Oxford University Press.

Wali, Kashi and Omkar N. Koul 1997, Kashmiri: A CognitiveDescriptive Grammar. London: Routledge.

Willson, Stephen 1999, Basic Burushaski Vocabulary. Studies in Languages of Northern Pakistan, vol. 6. Islamabad: National Institute of Pakistan Studies and Summer Institute of Linguistics.

Wilson, J. 1899, "On the Gurezi Dialect of Shina," in The Indian Antiquary 28: 93-102

Zoller, Claus Peter 2005, A Grammar and Dictionary of Indus Kohistani. Vol. 1: Dictionary. Berlin: Mouton de Gruyter. 
Gloss

$\underline{\text { Gilgiti }}$

$\underline{\text { Kohistani }}$

Guresi

Astori

Drasi

Brokskat

I. Body parts

1. armpit

2. beard

3. belly

4. blood

5 . bone

6. brain

7. breast

8. ear

9. elbow

10. eye

11. face

12. finger

13. fingernail

14. flesh

15. foot

\begin{tabular}{|c|c|c|c|c|c|}
\hline $\begin{array}{l}\text { gitíiti } \\
\text { dâãy }\end{array}$ & $\begin{array}{l}\text { gitíit } \\
\text { dáae }\end{array}$ & $\begin{array}{l}\text { kácị, gikúiti } \\
\text { dáĩ }\end{array}$ & $\begin{array}{l}\text { gikúiti } \\
\text { dấĩ }\end{array}$ & $\begin{array}{l}\text { khin, gikbití } \\
\text { dáae }\end{array}$ & $\begin{array}{l}\text { can'khon } \\
\text { smã'raa }\end{array}$ \\
\hline ḍeér & deér & dẹeér & deér & deér & wor \\
\hline léel & léel & léel & léel & léel & lyl \\
\hline âtịi & ấṭhi & ấṭi & ấṭi & áți & 'aatị \\
\hline máto & mótho, mágàz & maǵzíi, mótu & máto & móto & xor'mo \\
\hline cúcu & cíci & mámu & mam & mamế & kry, dut \\
\hline kon & kon & kon & koṇ & kon & ka'ni \\
\hline bakhúni & $\begin{array}{l}\text { thugúri, } \\
\text { photuúti }\end{array}$ & $\begin{array}{l}\text { bakhúni pl., } \\
\text { photuúti }\end{array}$ & bakhúni & bakhúni & khun \\
\hline achíi & açhíi & açhíi & açhíi & açhíi & a'çhii \\
\hline mukh & muk & muk, roói & mukh & mukh & 'undžuk \\
\hline haguí & hagwí & ãwर्̃ & anwĩ̃ & 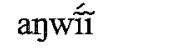 & 'guli \\
\hline nóoro & núuro & nóor & nóor & nóor & 'nurri \\
\hline moós & moós & moós & moós & moóst & moos \\
\hline páa & pããa & páa & páa & páa & 'kuti \\
\hline
\end{tabular}


Gloss

16. hair

17. hand

18. head

19. heart

20. kidney

21. knee

22. lip

23. liver

24. moustache

25. mouth

26. neck

27. nose

28. skin

29. shoulder

30. thumb

31. tongue

\section{$\underline{\text { Gilgiti }}$}

jakúr

hat

șiș

híyo

juk, zuk

kútọ

ỗọ̣o

yúum

phúne $p l$

ããy

șak

náto

com

phíco

agúto

jib

Kohistani
báal, jáako
hat
șị̣
hyưu
zuúk
kúthho
thurúuṭi
yũũ̃
phúgo
ããzi
șak
nóthi
com
phíjo, muṭh,
kaníi
hagúu
jip

\begin{tabular}{|c|}
\hline Guresi \\
\hline jakúu, báal \\
\hline hat \\
\hline șiíṣ \\
\hline híi, hŕiu \\
\hline júuk \\
\hline kúțu \\
\hline ỗọti \\
\hline yữũ \\
\hline phứũ๋ذ $p l$. \\
\hline ã̃ãzu \\
\hline šóoṇu, șak \\
\hline nótu. \\
\hline com \\
\hline phíjo, mițhíj \\
\hline ojũũutu \\
\hline \\
\hline
\end{tabular}

$\underline{\text { Astori }}$

\section{$\underline{\text { Drasi }}$}

Brokskat

jaáko

jakúu

'žokur

hat

hat

hat

șiíṣ siís

hyúu

híiu

șis

juk

kúto

õōt

yữũ

phúni $p l$.

ã̃ãzo

șak

náto

com

phéelo,

mithíjo

a)ứũto

jip

zuúk

h33

kxal'ma

'kuțo

'yți

$g^{\mathrm{j} i m}$

sam'dal

'uzi

grii, žin'gat

'nuto

'thuro

stod

gud 'guli

gip 


\begin{tabular}{|c|c|c|c|c|c|c|}
\hline Gloss & Gilgiti & $\underline{\text { Kohistani }}$ & Guresi & Astori & $\underline{\text { Drasi }}$ & Brokskat \\
\hline 32. tooth & don & don & don & don & don & da'nii pl.? \\
\hline 33. urine & miíke & mhiíki & $\begin{array}{l}\text { mữucư, } \\
\text { myaakul }\end{array}$ & mi1́ko & miíko & tshus \\
\hline \multicolumn{7}{|c|}{ II. Terms for kin and human beings } \\
\hline 34. brother & záa & z̧áa & jáa & záa & záa & 'baayo \\
\hline 35. brother's wife & jajeé & jazá & kaáki & jajeé & jajeé & $\begin{array}{l}\text { 'kaak'e, } \\
\text { chi'gaa }\end{array}$ \\
\hline 36. child & baál & baál & cúnu 'small' & baál & baál & si'naa \\
\hline 37. daughter & dií & dií & mulái, dií & diúh & mulái & mu'ley \\
\hline 38. daughter-in-law & nuúș & nuúș & nuúș & nuúṣ & nuúș & ntss \\
\hline 39. father & maálo, baábo & bubáa, maálo & maálu & baábo & bábo & boo \\
\hline 40. father's brother & picáa $^{1}$ & picáar & piçíi & cúno maálo & cúnọo bábo & 'sæno boo \\
\hline 41. father-in-law & šáyur & šéer & šéer & šáwur & šéer & šur \\
\hline 42. granddaughter & póoc̣i & póoc̣i & póoc̣i & póoçi & póoc̣i & 'pyyc̣i \\
\hline
\end{tabular}

1 Also: baro maálo 'elder father', cúno maálo 'younger father'. 


\begin{tabular}{|c|c|c|c|c|c|c|}
\hline Gloss & Gilgiti & Kohistani & Guresi & Astori & $\underline{\text { Drasi }}$ & Brokskat \\
\hline 43. grandson & póoc̣o & póoço & póoc̣o & póoço & póoço & 'pooc̣o \\
\hline 44. man & mušáa & mušáa & mušáa, mišáa & mušáa & mušáa & bуз $^{2}$ \\
\hline 45. mother & aáji, mãã & mãá, áji & mẫã, aáji & aáji & áaje & 'aae \\
\hline 46. mother's brother & $\begin{array}{l}\text { máamo, } \\
\text { moól }\end{array}$ & $\begin{array}{l}\text { mamáa, } \\
\text { mahuúl }\end{array}$ & múumū & móomo & móomoo & 'muumo \\
\hline 47. mother-in-law & šaṣ & šaș & šaš, șaș & șaṣ & šaṣ & šaș \\
\hline 48. name & nóom & núum & nóom & nóom & nóom & nũ̃̃ \\
\hline 49. person & manújo & manúuzo & manúuj̣u & manúuzo & manúuzo & muṣ \\
\hline 50. sister & sa & sas & sas & sas & káaki, sas & 'kaak'e \\
\hline 51. son & puc & puc & baál, puc̣ & puc̣ & baál $^{3}$ & ьузз \\
\hline 52. son-in-law & jamaçoó & jamçó & jamaçoó & jamaçoó & jamaçoó & ža'moo \\
\hline 53. wife's brother & šerií & šerii & šaerí & šairí & šayrí & šadže'rii \\
\hline 54. woman & cey & céi & céi & céi & céễ & $\begin{array}{l}\text { chi'gaa, } \\
\text { mu'ley }\end{array}$ \\
\hline
\end{tabular}

2 Not an error; same words provided by two separate speakers for 'son' and 'man'.

3 The same word was given for 'son' and 'child'. 
TABle 2: Comparative SHINA VocabularIes

\begin{tabular}{|c|c|c|c|c|c|c|}
\hline Gloss & $\underline{\text { Gilgiti }}$ & $\underline{\text { Kohistani }}$ & $\underline{\text { Guresi }}$ & Astori & $\underline{\text { Drasi }}$ & Brokskat \\
\hline \multicolumn{7}{|c|}{ III. Human artifacts } \\
\hline 55. arrow & kóoṇ & kóoṇ & tîir, kóoṇ & kóoṇ & kóon & daah \\
\hline 56. ashes & dáal & šóo & dáal & dáal & dáal & thal'tsir \\
\hline 57. bed & šéen & šen & khaț, caarpái & khat & paláj, caarpái & car'pii \\
\hline 58. bread & ț̣iki & țîki, tịkki & ț̣iki & țîki & ț̣íkki & man'nili \\
\hline 59. churn & tharígi & chapóoro & çhapáru & jagú & $\begin{array}{l}\text { gurgúr, } \\
\text { chapáro }\end{array}$ & tha'rini \\
\hline 60. curds & múuțo dut & múutho dut & $\begin{array}{l}\text { cúrku dut, } \\
\text { méel, burús }\end{array}$ & cúrko dut & mótọ dut & gaan \\
\hline 61. dream & sã̃ãce $p l$. & sáaçho & sáaçu & sẫạco & sáaço & 'șaaçii pl.? \\
\hline 62. fertilizer & páaș, swaác̣ & páaș & páaș & páaș & páaș & pưš \\
\hline 63. field & çhéeç, bári & dóoli & çhéec̣ & çhéec, khái & çhéeș & bun, kheey \\
\hline 64. fire & $\begin{array}{l}\text { agáar, } \\
\text { hagáar }\end{array}$ & phúu & pfúu, angáaru & phúu & phúu & goor \\
\hline 65. ghee & gií & gií & gií & gií & daí lojuúli & $\mathrm{g}^{\mathrm{j} i \mathrm{i}}$ \\
\hline 66. grease & mî̃̃ & myứ, carbíi & mữ & mî̃u & mî̃ & $\min$ \\
\hline 67. handspan & diṭ & diș & drísțti & dișt & dișt & dit \\
\hline
\end{tabular}




\begin{tabular}{|c|c|c|c|c|c|c|}
\hline Gloss & Gilgiti & Kohistani & Guresi & Astori & Drasi & $\underline{\text { Brokskat }}$ \\
\hline 68. honey & machíi & maçíi & machíi & machíi & machíi & gjãã 'tsi \\
\hline 69. house & góoț & góoṣ & $\begin{array}{l}\text { góoș, } \\
\text { šikáar }\end{array}$ & goóș & góoș & goot \\
\hline \multicolumn{7}{|l|}{ 70. irrigation } \\
\hline channel & yap, ก்̃1 & yab, íil & yab, îil & yap, f́il & yap, íil & $g^{j} a b$, șka \\
\hline 71. loom & hésko & éeṇi & luțhúru, vaán & no data & $\cos$ & thak'saa \\
\hline 72. mattock (hoe) & $\begin{array}{l}\text { phyốõli, } \\
\text { gențí }\end{array}$ & $\begin{array}{l}\text { pheélo, } \\
\text { gentí }\end{array}$ & $\begin{array}{l}\text { phyốõli, } \\
\text { gențí }\end{array}$ & bel, gintị & $\begin{array}{l}\text { thokteé, } \\
\text { phyốorịi, gintí }\end{array}$ & thok'tse \\
\hline 73. milk & dut, aṇaáwo & dut & dut & dut & ãṇnẫũ, dut & $3^{\prime} d z ̌ e n$ \\
\hline 74. path & pon & pon & pon & pon & pon & pon \\
\hline 75. plow & hal & hal & hal & hal & hal & hal \\
\hline 76. roof & táši & šaróon & šarún, tal & šarín & šeróon & 'šaltaa \\
\hline 77. salt & pajúu & luúnịi & luúṇi & pajúu & luúṇi & pa'yш \\
\hline 78. sickle & bisáac̣, leéc̣ & léeçi & óno, ốni & dáli & $\begin{array}{l}\text { óono, } \\
\text { yóo léec̣i }\end{array}$ & bo'șuns \\
\hline 79. smoke & duúm & duúm & duúm & duúm & duúm & $d u t$ \\
\hline 80. spinning wheel & cárko & cágar & yõș & caáko & cáku & caq \\
\hline
\end{tabular}


TABLE 2: COMParative Semna Vocabularies

\begin{tabular}{|c|c|c|c|c|c|c|}
\hline Gloss & Gilgiti & Kohistani & Guresi & Astori & Drasi & Brokskat \\
\hline 81. village & kúi, het & kóoț & kwíi & giróom, het & kwii, gã̃ãm & bun \\
\hline 82. wood & káațo, juk & káațho & káațo & káațho & káațo & 'kooț \\
\hline 83. work & kom & kom & krom & krom & krom & krom \\
\hline \multicolumn{7}{|c|}{ IV. The sky, weather } \\
\hline 84. blue sky & béej̣i & bízi & béju & - & - & - \\
\hline 85. cloud & burgaál, ájo & ázo & áj̣u, kavúu & ázo & ázo & á'ẓeș \\
\hline 86. lightning & bícuṣ & bícaṣ & bícuș, traṭ & bicúṣ & bícuṣ & brok \\
\hline 87. moon & yúun & yúun & yúun & yúun & yúun & $\mathrm{g}^{\mathrm{j}} \mathrm{un}$ \\
\hline 88. rain & ájo & ázo & áju & ázo & ázo, mế̃ & char'cht \\
\hline 89. sky & agaáy, hagáay & asmán & aygaái & asmán & ayấi & do'lo \\
\hline 90. snow & hin & hin & hin & hin & hin & 'azo \\
\hline 91. star & táaro & táaro & táaru & táaro & táaro & 'turi \\
\hline 92. sun & súuri & súuri & súuri & súuri & súuri & 'stri \\
\hline 93. water & wey & wói, wíi & vói & wói & wói & w33 \\
\hline 94. wind & ốõši, óoši & óoši & îši, óoši & óoši & óoṣ & YYš \\
\hline
\end{tabular}


TABLE 2: COMPARATIVE SHINA VoCABULARIES

\begin{tabular}{|c|c|c|c|c|c|c|}
\hline Gloss & $\underline{\text { Gilgiti }}$ & Kohistani & $\underline{\text { Guresi }}$ & Astori & $\underline{\text { Drasi }}$ & Brokskat \\
\hline \multicolumn{7}{|c|}{ V. Time and space } \\
\hline 95. afternoon & balakaál & peeší & peešín & dazoó & $\begin{array}{l}\text { belukhén, } \\
\text { bazukhén }\end{array}$ & $\begin{array}{l}\text { ba'zun, } \\
\text { taas ha'ray }\end{array}$ \\
\hline 96. autumn & šaróo & šaryóo & šaróo & šaróo & šatóo & 'yuuno \\
\hline 97. day & déez, chak & deés, chak & $\begin{array}{l}\text { dées, chak, } \\
\text { súuri }\end{array}$ & déez & dées & dis, 'stri \\
\hline 97a. Saturday & šimšér & - & bațaár & šimšér & bațavaár & no data \\
\hline 97b. Sunday & adít & itváar & $\begin{array}{l}\text { aitvaár, } \\
\text { áathæ̇ vaár }\end{array}$ & adít & adít & no data \\
\hline 97c. Monday & tsandúro & suwáar & tsãdraár & tsandráalo & tsãdraál & no data \\
\hline 97d. Tuesday & aygáaro & - & bóyu vaár & angáaro & angáaro & no data \\
\hline 97e. Wednesday & bóodo & - & bodvaár & bóodo & bóodo & no data \\
\hline 97f. Thursday & bréspat & - & brestvaár & bréspat & brésput & no data \\
\hline 97g. Friday & šúkur & jumá & jumáh & šúkur & jumẫã & no data \\
\hline \multicolumn{7}{|l|}{ 98. day after } \\
\hline tomorrow & ceírin & mút-chak & çiíri & çíżi & çiírye & çe dis \\
\hline 99. down(hill) & khíri & khári & khári & laáthini & khári & khah \\
\hline
\end{tabular}


TABLE 2: COMPARATIVE SHINA VOCABULARIES

\begin{tabular}{|c|c|c|c|c|c|c|}
\hline Gloss & $\underline{\text { Gilgiti }}$ & $\underline{\text { Kohistani }}$ & Guresi & Astori & Drasi & Brokskat \\
\hline 100. east & jil bey & nur xáataa & mašrik & mašrík & súuri déen warí & šar \\
\hline 101. evening & šáam & beláa(r) & šáam & bazúko & šáam & bal'bul, \\
\hline & & & & & & 'belday \\
\hline 102. month & máaz & móos & móos & móos & móos & no data \\
\hline 102a. Vaisakha & - & besáak & vaaék, wáihek & - & - & (Tibetan) \\
\hline 102b. Jestha & - & jéețh & jéețh, zeeșt & - & - & \\
\hline 102c. Asadh & - & har, haaṛh & háa & - & - & \\
\hline 102d. Sravan & - & paškál & šáawon & - & - & \\
\hline 102e. Bhadra & - & bhaadró & badirét, báadret & 一 & - & \\
\hline 102f. Ashvina & - & ássu & - & - & - & \\
\hline 102g. Kartika & - & katák & kártik, kartiik & - & - & \\
\hline 102h. Marga & - & magár & magár & - & - & \\
\hline 102i. Pausha & - & póo & póo, poohóo & - & - & \\
\hline 102j. Magha & - & - & máag & - & - & \\
\hline 102k. Phalguna & - & phagán & phagún & - & - & \\
\hline 1021. Chaitra & - & ceetár & tsíithir & - & - & \\
\hline
\end{tabular}




\begin{tabular}{|c|c|c|c|c|c|c|}
\hline Gloss & $\underline{\text { Gilgiti }}$ & $\underline{\text { Kohistani }}$ & Guresi & Astori & Drasi & Brokskat \\
\hline 103. morning & $\begin{array}{l}\text { calbúc, } \\
\text { luștikaál }\end{array}$ & loṣkí & lóoșt, lóoșteĩ & lóoșteĩ & $\mathrm{cal}$ & 'cwalto \\
\hline 104. night & ráati & ráati & ráati & ráati & ráati & raat \\
\hline 105. sunny side of & sứuri deéç, & & & & & \\
\hline mountain & suréen & suréen & suréen & suréen & suryóon & $n^{\mathfrak{j}}$ in mys \\
\hline $\begin{array}{l}\text { 106. shady side of } \\
\text { mountain }\end{array}$ & $\begin{array}{l}\text { cijoót, } \\
\text { 'shadow' }\end{array}$ & chóri & chóri & cijoót & churyóon & grib \\
\hline \multicolumn{7}{|l|}{ 107. seasonal } \\
\hline migration & ucáai & ujaái & darốõ bojoónu & - & niríl & 'paae 'nakhlis \\
\hline 108. spring (season) & bazoóno & bazoódo & bazoónu & bazanoó & uẓáalo & ba'zun, 'uulo \\
\hline 109. summer & uwáalo & wáalo & wáalu & wáalo & bazoóno & 'wulo, ba'zun \\
\hline 110. today & aš & aš & aš & aš & aš & aš \\
\hline 111. up(hill) & ají(t) & ají, húuṇ & ajá & utháli & ajá & hun \\
\hline 112. west & buúr bey & qablá & magrib & magrib & súuri béen warí & $\mathrm{n}^{\mathrm{j}} \mathrm{ub}$ \\
\hline 113. winter & yoóno & yoódo & yoónu & yoóno & yoóno & 'yuuno \\
\hline 114. year & $\begin{array}{l}\text { kaál, barîs, } \\
\text { sáal, awéelo }\end{array}$ & kaál & avéelu & sáal & awéelo & lo'kyr, saar \\
\hline
\end{tabular}


Gloss

\section{VT. Earth}

115. earth

116. earthquake

117. forest

118. highest summer pasture

119. hill

120. mountain

121. river

122. sand

123. spring (of water)

124. stone

\section{TABLE 2: COMPARATIVE SHINA VocABULARIES}

$\underline{\text { Gilgiti }} \underline{\text { Kohistani }} \underline{\text { Guresi }} \underline{\text { Astori }} \underline{\text { Drasi }}$ Brokskat

\begin{tabular}{|c|c|c|c|c|c|}
\hline $\begin{array}{l}\text { sum, birdí } \\
\text { bũyấl } \\
\text { jeél }\end{array}$ & $\begin{array}{l}\text { sum, uzmúke } \\
\text { myaál } \\
\text { jeél }\end{array}$ & $\begin{array}{l}\text { zamúin } \\
\text { mũyál, bunîlu } \\
\text { jeél }\end{array}$ & $\begin{array}{l}\text { sum } \\
\text { zilzilá } \\
\text { jaygál }\end{array}$ & $\begin{array}{l}\text { kwíi } \\
\text { bũcáal, tsangúl } \\
\text { jangál, jeél }\end{array}$ & $\begin{array}{l}\text { pзз } \\
\text { tsan'gul } \\
\text { tshoq, } \\
\text { džan'gal }\end{array}$ \\
\hline niriíl & maáli & niríl & niríl & šáay & $\begin{array}{l}\text { 'zulo tsib } \\
\text { caris, nag'lis }\end{array}$ \\
\hline tḥóko, huc̣ & ṭ̂́óko, huc̣ & ṭhóku, huc̣ & thúko & thúko & zun \\
\hline chữĩs, khan & khon khan & khoṇ, chíiș & çhíiș & šáay & zun \\
\hline $\sin , \mathrm{ga}$ & sin, ga & sin, gáa & sin, gah & $\sin$ & $\sin$ \\
\hline sígal & sígal & sínil & sínel & sínel & 'siri \\
\hline uts & utsh & uts & uts & uts & 'motsur \\
\hline bat & bat & bat & baț, gíiri & baț & 'naaro \\
\hline
\end{tabular}




\begin{tabular}{|c|c|c|c|c|c|c|}
\hline Gloss & Gilgiti & Kohistani & Guresi & Astori & Drasi & Brokskat \\
\hline \multicolumn{7}{|l|}{ VII. Animals } \\
\hline 125. ant & philíili & phibíili & pfilińli & philíili & philíili & pi'nili \\
\hline 126. ass & jakún & zakún & jakưun & zakún & zakún & kxar \\
\hline 127. bear & $\tilde{\mathbf{I} c}$ & ich & iç & ic̣ & iș & dẹen'mo \\
\hline 128. bird & brin & min 'pheasant' & jaanəwáar & cáaĩ & cǽæĩ & 'cešok thoq \\
\hline 128a. sparrow & haráçin & cayaá & cái & - & 一 & - \\
\hline 129. bull & dóono & bhaák & dóonu & dóono & dóono & zo, lay'țo \\
\hline 130. bumblebee & ḍựúyo & $\begin{array}{l}\text { guygúuto, } \\
\text { bhoráa }\end{array}$ & zombuú & - & zombuú & uș'kuṭo \\
\hline 131. cat $m$. & búušo & púšo & púšsu, gáñju & píšo & gájo, pišu & bi'leut \\
\hline 132. cat $m$. & búuši & púši & púši & píši & pišu & bi'le\# \\
\hline 133. crow & kấã & qáa & káa & káa & kórkuts & qoo \\
\hline 134. cow & goó, gáaw & gáao & gaáu & gaáo & gaáo & goo \\
\hline 135. dog & $\check{\text { šũ }}$ & šú̃ũ & šú̃̃ũ & sũ̃ũ & sũ̃ũ & šwaa \\
\hline 136. egg & haṇeé & hanóó & hanõố, thuuúl & țhuúl & thuúl & thul \\
\hline 137. feather & $\begin{array}{l}\text { phurguú, } \\
\text { paçháali }\end{array}$ & paçháali & páṭu & tíiri & páto & șok'paa \\
\hline
\end{tabular}


TABLE 2: COMPARATIVE SHINA VOCABULARIES

\begin{tabular}{|c|c|c|c|c|c|c|}
\hline Gloss & $\underline{\text { Gilgiti }}$ & $\underline{\text { Kohistani }}$ & Guresi & $\underline{\text { Astori }}$ & $\underline{\text { Drasi }}$ & Brokskat \\
\hline 138. fish & chúmu & chúbo & chími, chúmo & chúmo & chímo & nyãã \\
\hline 139. flea & pî́ịo & píizo & príị̣o & príizu & príizo & 'puzo \\
\hline 140. goat $m$. & múgar & thoot, múgar & chatíilu & thóo & chatíilo & 'miar, ža'too \\
\hline 141. goat $m$. & ã̃i, ái & ái & ái & ái & ái & $\begin{array}{l}\text { 'aau, 'chaati, } \\
\text { chal }\end{array}$ \\
\hline 142. hen & karkaámuš & kukwĩi & kokói & karkaámuc ${ }^{4}$ & kokoó & byaa mo \\
\hline 143. horn & șíno & șígo & šínu & șín & șíno & șín \\
\hline 144. horse & ấšpo & ášpoo & ãšp, ãšsip & ãšip & ãšup & aav̌š \\
\hline 145. louse & jưứ & jũû́ & jũû́ & juú & juú & žwaa \\
\hline 146. louse (nit) & liíc̣ & liíc̣ & liíc̣ & liíc & lic̣í $p l$. & liç'aa \\
\hline 147. mouse, rat & múuji & múuzo & múuj̣u & múuj̣i & múuzi & 'metuzi \\
\hline 148. rooster & kajkaroóco & kukû́ũ & kokoó & kaykaroóco ${ }^{5}$ & bíiro kokoó & byaa pho \\
\hline 149. sheep & éji & laç & laç & ijíilo & laṣ & ni'lo \\
\hline 149a. ewe & éji, ijíili & eš & eš & eš & eš & eey \\
\hline 149b. ram & karéelo, un & karaá & karaá, šaróoṭu & karéelo & karéelo & churr'di \\
\hline
\end{tabular}

4 Shina of Nager.

5 Shina of Nager. 


\begin{tabular}{|c|c|c|c|c|c|c|}
\hline Gloss & $\underline{\text { Gilgiti }}$ & Kohistani & $\underline{\text { Guresi }}$ & Astori & $\underline{\text { Drasi }}$ & Brokskat \\
\hline 150. snake & jon & judraá & jon & jon & jon & žun \\
\hline 151. tail & phacoó & lamțoó & lamóoțu, lamțoó & lamóți & lamúți & pi ç̣oo \\
\hline 152. wasp & iškáar & çubúu & bũyaári & zombuú & çazáa & $\operatorname{ton}^{\prime} z e$ \\
\hline \multicolumn{7}{|c|}{ VIII. Plants and trees } \\
\hline 153. apple & phalaá & paloó & paloó & paloó & paloó & pa'laa \\
\hline 154. apricot & jaroóṭi & zaroótọ & $\begin{array}{l}\text { phatóor } \\
\text { jaroóți pl. }\end{array}$ & jaroóți & pharóor & phaa'țir \\
\hline 155. bark (of tree) & dílo & dílo & delú & dílo & dílo & phar'put \\
\hline 156. barley & yóo & yóo & yóo & yóo & yóo & góno \\
\hline 157. birch & buc & jốõzi & jóoji & jốōzi & jóozii & 'zozozi, zuuru'zi \\
\hline 158. cedar & phuluúș & phulúuẓo & déva daár, cíi & cilíi & díiv daár & dyo'daar \\
\hline 159. fig (fruit) & phaág & phagwíi kúla & $\begin{array}{l}\text { kãã ấšip, } \\
\text { phațóoru }\end{array}$ & pfaák & injüir & an'jiir \\
\hline 160. grape(s) & jaç & zaç & daș, dásțtom & jaç & daș & zasạ \\
\hline 161. grass/fodder & kaç, car & kac̣ & kaç & no data & kaș & gaas \\
\hline 162. leaf & páto & páțho & páțu & páto & páțo & pan'nii \\
\hline
\end{tabular}


Table 2: Comparative Shina VocabUlaries

\begin{tabular}{|c|c|c|c|c|c|c|}
\hline Gloss & Gilgiti & $\underline{\text { Kohistani }}$ & Guresi & Astori & $\underline{\text { Drasi }}$ & Brokskat \\
\hline 163. maize & makáy & makái & makái & makíi & makái & chah, mak'kii \\
\hline 164. mulberry tree & maróoc̣ & maróoc̣o & marúc ç & maróoç & maróoș & ma'rõõṣ \\
\hline 165. pomegranate & daṇû́ũ & daṇúũ & daṇú & daṇû́ũ & anáar & a'nar \\
\hline 166. poplar & phaltsí & no data & phrãts & phrats & fras & phal'tsaa \\
\hline 167. root & mulií & cherís & chirís & chiríṣ & chilíṣ & pat'taq \\
\hline 168. seed & bíi & bíi & bíi & bíi & bíi & bii \\
\hline 169. tree & múto, tom & mútho, tom & tom & tom & byéĩ & $\begin{array}{l}\text { šin'tso, } \\
\text { laq'tshuks }\end{array}$ \\
\hline 170. walnut & açhoó & açhoó, khakáy & açhoó & kakáĩ & achoó & $a^{\prime}$ çhoo \\
\hline 171. willow & bew & byõ & béĩ & no data & byéĩ & can'ma \\
\hline \multicolumn{7}{|l|}{$L X$. Verbs } \\
\hline 172. to beat & zamoók & ḍagoón & kutyoónu & kuțoónu & kutyoóno & khu'tis \\
\hline 173. to bite & capoók & capoón & capyóonu & jan thoónu & jan thyoóno & can this \\
\hline 174. to burn $i$. & dajoók & dajoón & dajoónu & dajoónu ${ }^{6}$ & dajoóno & 'daažis \\
\hline
\end{tabular}

6 Some nasalization on the suffix, dajốñnu 
TABLE 2: Comparative Shina VocabUlaries

\begin{tabular}{|c|c|c|c|c|c|c|}
\hline Gloss & $\underline{\text { Gilgiti }}$ & $\underline{\text { Kohistani }}$ & $\underline{\text { Guresi }}$ & Astori & $\underline{\text { Drasi }}$ & Brokskat \\
\hline 175. to burn $t r$. & dayoók & dahoón & dayoónu & dayoónu & dayoóno & 'daahis \\
\hline 176. to come & wayoók & ayoón & oónu, ayoónu & wazoónu & oóno & is \\
\hline 177. to cry & roók & roón & $\begin{array}{l}\text { hívi dyoónu, } \\
\text { roónu }\end{array}$ & roónu & roóno & rus \\
\hline 178. to die & miroók & miryoón & miryoónu & miróonu & miryoóno & mi'nis \\
\hline 179. to drink & piyoók & pyoón & piyoónu & piyoónu? & piyoóno & pis \\
\hline 180. to eat & khoók & khoón & khoónu & khoónu & khoóno & kxus \\
\hline 181. to fly & thar doók & thor doón & talée dyoónu & hun boónu & talwí dyoóno & $u^{\prime}$ this \\
\hline 182. to give & doók & doón & dyoónu & doónu & dyoóno & dis \\
\hline 183. to go & bujoók & bojoón & bojoónu & bujoónu & bojoóno & byaas \\
\hline 184. to harvest & $\begin{array}{l}\text { leéç thoók, } \\
\text { loók }\end{array}$ & loón & lyoónu & curúk thoónu & lyoóno & 1335 \\
\hline 185. to hear & parujoók & șuṇoón & parjoónu & parjoónu & parjoóno & kon this \\
\hline 186. to kill & maroók & maroon & maryoónu & maroónu & maryoóno & ma'ris \\
\hline
\end{tabular}

7 piyó́nu 
TABLE 2: COMPARATIVE SHINA VOCABULARIES

\begin{tabular}{|c|c|c|c|c|c|c|}
\hline Gloss & Gilgiti & $\underline{\text { Kohistani }}$ & $\underline{\text { Guresi }}$ & $\underline{\text { Astori }}$ & $\underline{\text { Drasi }}$ & Brokskat \\
\hline 187. to know & $\begin{array}{l}\text { daștoók, } \\
\text { sũyoók }\end{array}$ & $\begin{array}{l}\text { laçhoón, } \\
\text { siyoón }\end{array}$ & daștyoónu & daș̣hoónu & daștyoóno & žzts \\
\hline 188. to laugh & $\begin{array}{l}\text { hayijoók, } \\
\text { hayoók }\end{array}$ & hazoón & hajoónu & hazoónu & háaji thyoóno & 'haazis \\
\hline 189. to lie (down) & $\begin{array}{l}\text { jeék boók, } \\
\text { țaám boók }\end{array}$ & zeeék boón & țam boónu & jẹ boók & dil boóno & stus \\
\hline 190. to say & rayoók & razoón & rajoónu & razoónu & rajoóno & 'raazis \\
\hline 191. to see & $\begin{array}{l}\text { pašoók, } \\
\text { çakoók }\end{array}$ & $\begin{array}{l}\text { pašoón, } \\
\text { çakoón }\end{array}$ & $\begin{array}{l}\text { pašoónu, } \\
\text { çakyoónu }\end{array}$ & çakoónu & çakyoóno & skis \\
\hline 192. to sit & bayoók & byoón & byoónu & biyoónu & biyoóno & bз3s \\
\hline 193. to sleep & soók & níiṣ thoón & soónu. & soónu & soónu & stus \\
\hline 194. to stand & $\begin{array}{l}\text { cóko book, } \\
\text { uthyoók }\end{array}$ & $\begin{array}{l}\text { cóko boon, } \\
\text { uthyoón }\end{array}$ & cok boónu & hun boónu & uthyoóno & u'this \\
\hline 195. to swim & $\begin{array}{l}\text { tam doók } \\
\text { taroók }\end{array}$ & taroón & $\begin{array}{l}\text { núuš dyoónu, } \\
\text { tam dyoónu }\end{array}$ & tam doónu & noošyoóno & Škela'ris \\
\hline 196. to walk & yayoók & yaazoón & yajoónu & yazoónu & yažoóno & zaa'zis \\
\hline 197. to wash $t r$. & dujoók & dijaaroón & dijaaryoónu & dijaroónu & dowæǽno & $\mathrm{dus}$ \\
\hline
\end{tabular}




\begin{tabular}{|c|c|c|c|c|c|c|}
\hline Gloss & $\underline{\text { Gilgiti }}$ & $\underline{\text { Kohistani }}$ & $\underline{\text { Guresi }}$ & Astori & Drasi & Brokskat \\
\hline \multicolumn{7}{|l|}{$X$. Adjectives } \\
\hline 198. all (sārā) & búțo $s g$. & básko & básko & púuro & búro & cuk \\
\hline 199. all (sab) & búta $p l$. & búta & búțị, láa & púuro & láa, bucé & cuk \\
\hline 200. big & bárọo & báṛ̣o & bárụ & bárọo & báro & 'bono \\
\hline 201. bitter & çíto & cíto & cítu & cíto & cíto & 'çițo, 'ṭiito \\
\hline 202. black & kíno & kíno & kínu & kíno & kíno & 'kyono \\
\hline 203. blind & șéwo & șéeo & šéeu & șeéo & șéeo & žar'baa \\
\hline 204. cold & šidálo & ç̣hahứũ & çaứũu, çawữ̃̃ & çaṹũ & caamúũu & 'cyya \\
\hline 205. dry & súkho & šúkho & šúku & šúku & šúko & 'šuko \\
\hline 206. eight & ãș & ãș & ãșt & ãș & ãșt & aș \\
\hline 207. eighteen & așțããy & așțã̃ãi & ãșțáai & așțããã & așțáai & aș'țõš \\
\hline 208. eleven & akáay & akáai & akáai & akáai & akáai & 'qudeš \\
\hline 209. few & aápe & ápa & jéek, ápo & ápo & céek & 'apo, kjii \\
\hline 210. fifteen & panzéy & panzílee & pãzulế̃̃ & pazilí & pazilế̃̃ & 'pããdeš \\
\hline 211. five & poš & poš & põs̆ & põš & põš & põõs̆ \\
\hline 212. forty-one & díbu-ga ek & díbu-ga ek & dúbi-gə ek & díbu-ga ek & díbyu-ga ek & 'dobužu 'ek \\
\hline
\end{tabular}


Table 2: Comparative Shina Vocabularues

\begin{tabular}{|c|c|c|c|c|c|c|}
\hline Gloss & $\underline{\text { Gilgiti }}$ & Kohistani & Guresi & Astori & Drasi & Brokskat \\
\hline 214. fourteen & coóndei & cahứdee & codếi & coódẽ̃̃ & codéĩ & 'curdeš \\
\hline 215. full & șek, șak & phúuno & șek & șek & phúuṇo, pují & 'punjis, pe'ree \\
\hline 216. good & míșțo, sam & míștho, sam & míșțhu, siyóo & misșțhu & síi, šabóko & 'țaalo \\
\hline 217. green & núilo & níilo & níilu & nílu & níilo & 'niilo \\
\hline 218. hot & taáto & táto & tátu & tátto & tátto & 'taato \\
\hline 219. hundred & šal & šal & šal & Šal & šal & šo \\
\hline 220. hungry & uyáno, niráno & niroóno & unyaálu, niróṇu & nirónu & niróno & thaa, țhan'yaa \\
\hline 221. left (direction) & khábo & khabóoto & kha, khái & kháau & khaibón & $\mathrm{h}^{\mathrm{j}}$ in \\
\hline 222. long & jógo & zígo & joígu & zígu & jíno & 'zuigo \\
\hline 223. many & $\begin{array}{l}\text { laáwo, } \\
\text { tušáar }\end{array}$ & láa & tišáar, láa & láa & mága láu & 'bede \\
\hline 224. new & naáwo & nốõ & nắã & náũ & náao & nyy \\
\hline 225. nine & naw & nã̃õ & náu & náu & náũ & nũũu \\
\hline 226. nineteen & kunií & ukanú̃ & kunií & kuniih & kunijh & 'kunjaa \\
\hline 227. old (person) & járo & járo & járu & járo & járo & 'jaaro \\
\hline 228. one & ek & ek & ek & ek & ek & ek \\
\hline 229. red & loólyo & lhiílo & loólu & loólo & loólo & 'looðo \\
\hline
\end{tabular}




\begin{tabular}{|c|c|c|c|c|c|c|}
\hline Gloss & Gilgiti & Kohistani & Guresi & Astori & $\underline{\text { Drasi }}$ & Brokskat \\
\hline 230. right (direction) & $\begin{array}{l}\text { daçhíno, } \\
\text { daçhiboóm }\end{array}$ & daçhíno & daçínu & dașínu & daștibón & tran wu'ji \\
\hline 231. round & biḍiríko & ḍiḍuúro & ḍuḍuúru & ḍiḍuúro & kirkíro & $\begin{array}{l}\text { dĩ'duuro, } \\
\text { 'rilbu }\end{array}$ \\
\hline 232. seven & sat & sat & sat & sat & sat & sat \\
\hline 233. seventeen & sattẫãy & sattã́ã̃ & sattáai & sattã̃ã & sattáai & sat'tõõš \\
\hline 234. sharp & tíino & tíino & tîinu & tíino & tíinọo & 'ṭino, tsap tsap \\
\hline 235. six & șa & șa & șa & șa & șa & șaa \\
\hline 236. sixteen & șỗõy & șốõi & șốõi & șóĩ & șỗõi & 'șobeš \\
\hline 237. small & cúno & cúnọo & cúṇu & khúṭu & cúnọo & 'titaq, 'sææno \\
\hline 238. sour & cúrko & cúko & cúrku & cúrko & cíțo & 'cukro \\
\hline 239. ten & day & dáai & dái & dái & dái & daaṣ \\
\hline 240. thirteen & ç̣̂̃õy & çóoi & çói, cóoi & çóĩ & ç̣̂̃̃̃̃ & trobeš \\
\hline 241. thirty-nine & bií-ga kunií & bhyo ukañ̃u & bi-gə kunií & bií-ga kuniîh & bií-ga kuniîh & 'bizu 'kunjaa \\
\hline 242. three & çée & cée & çe & çée & çée & traa \\
\hline 243. thousand & hazáar, sãã́s & zir & sáas & dái šal & sáas & 'ston \\
\hline 244. twelve & báay & báai & báai & báai & bwáai & 'budeš \\
\hline
\end{tabular}


TABle 2: COMPARATIVE SHINA VocabULARIES

\section{$\underline{\text { Gloss }}$}

245. twenty

246. twenty-nine

247. two

248. white

249. yellow

XI. Pronouns etc.

250. he

251. I

252. not

253. she

\section{$\underline{\text { Gilgiti }}$}

bií

bií-ga naw

dúu

šáyo

halịjo

\section{$\underline{\text { Kohistani }}$}

bií

bhyo nã̃

dúu

šóo

píilo

\section{ro, ros}

ri, ris pl.

ma, mas

ne, neé

re, res

Guresi
bií
bi-gə náu
dúu
šóo
píilu,
kumû́ũmu
so, j̣o, aá
senố, jesễ்̃̃,
aásễĩ

$\underline{\text { Astori }}$

bií

bií-ga náu

du

šéeo

komúmo

mu?, mẽ̃

mo, mõ

na, nẽế, niš

sa, sésoo mur,

se, je, aá

sésõ, jésõ,

aásõ $\underline{\text { Drasi } \quad \text { Brokskat }}$

bií

no data

$\mathrm{du}$

syóo

gúuro

pho

biži'nũũu

dett

šoo

hal' dzuro

mõ

nuš

pho mu'ley 


\begin{tabular}{|c|c|c|c|c|c|c|}
\hline Gloss & $\underline{\text { Gilgiti }}$ & $\underline{\text { Kohistani }}$ & $\underline{\text { Guresi }}$ & Astori & Drasi & Brokskat \\
\hline 254. they $m$. far & oó & sa, seṇáa & se, je, aá & no data & zee, paraá, & 'pheeu \\
\hline 255. they $f$ far & oó & sa, seṇáa & $\begin{array}{l}\text { sǽæ, j̣ǽæ, } \\
\text { ayáa } \\
\text { sǽæs, j̣ǽæs, } \\
\text { ayáas }\end{array}$ & no data & zo, paraáo & 'pheeu \\
\hline 256. they $\mathrm{m}$. near & no data & ye, yeṇáa & anyáa & no data & zee, anú & $a^{\prime} l o$ \\
\hline 257. they $f$ near & no data & ye, yeṇáa & anyáa & no data & zæ, aní & a'lo \\
\hline 258. that $m$. & oó & asá, asési & peraá, paraá & no data & paraáo & $a^{\prime} l o$ \\
\hline 259. that $f$. & eé & asá, asésoo & no data & aá & no data & no data \\
\hline 260. this $m$. & anú, anús & aáe, aáysi & anú, nu & anúh & anúh, aá & $a^{\prime} l a m$ \\
\hline 261. this $f$ & ané, anés & aáe, aáysoo & aní & aníh & no data & no data \\
\hline 262. these & $\mathrm{ni}, \mathrm{nis}$ & aáe & no data & no data & no data & no data \\
\hline 263. we & be, bes & be, asáa & be? & be, bes & be & bey, b33 \\
\hline 264. what? & jéek, je & jóo, káa & jóok & yóok & jok & yee \\
\hline
\end{tabular}




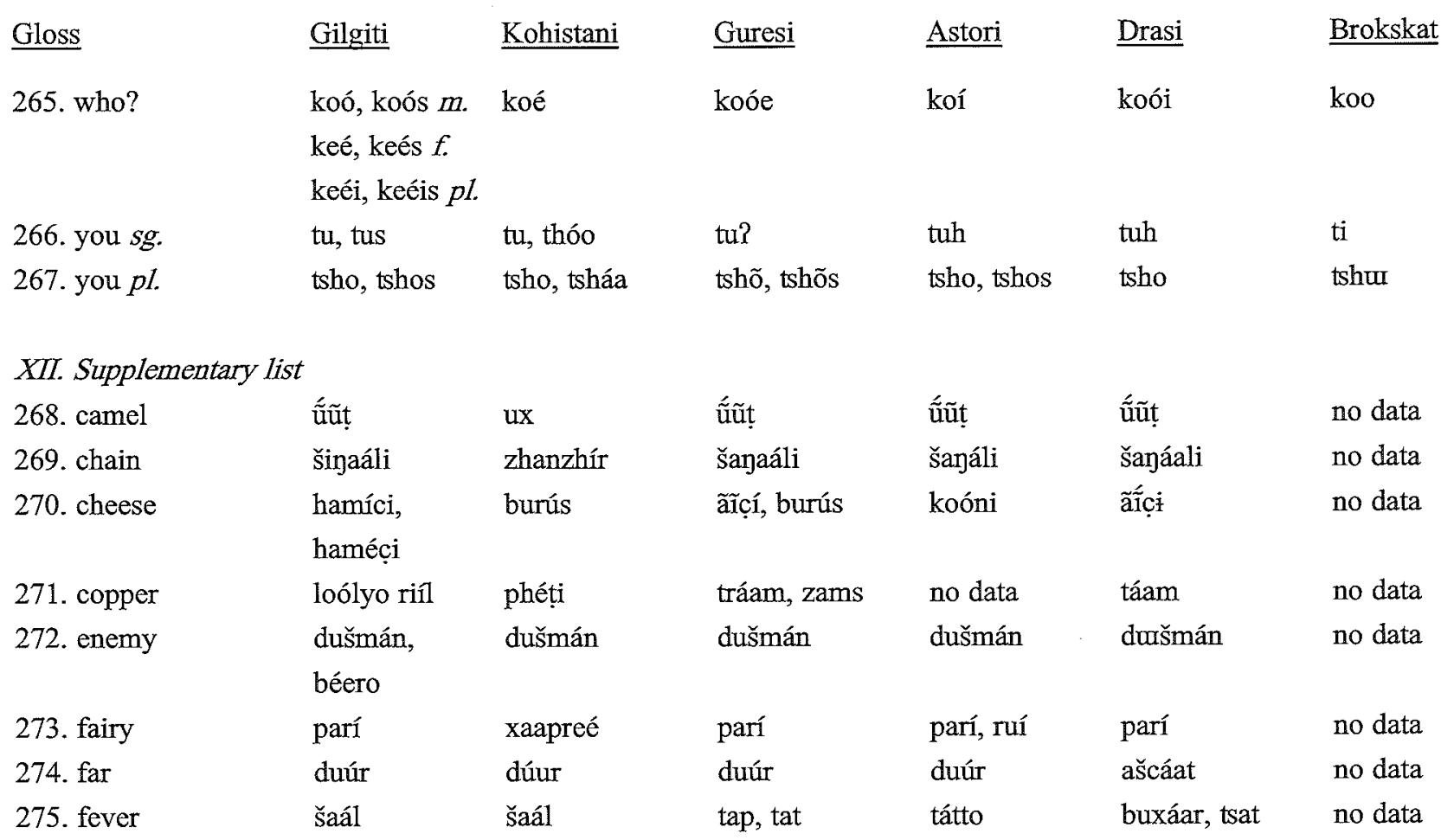




\begin{tabular}{|c|c|c|c|c|c|c|}
\hline Gloss & $\underline{\text { Gilgiti }}$ & $\underline{\text { Kohistani }}$ & $\underline{\text { Guresi }}$ & Astori & Drasi & Brokskat \\
\hline 276. flour & ã̃ãte & phuk & áațe & ããte & ã̃ățe & no data \\
\hline 277. foam & phíin & phéen & phíinại & $\begin{array}{l}\text { phíini } \\
\text { phíini }\end{array}$ & pfiin & no data \\
\hline 278. fox & lối & lói & lói & lói & lói & no data \\
\hline 279. frog & maṇúuko & maṇóoq & manộ̃õk & maṇóoko & maṇốõk & no data \\
\hline 280. gold & soṇ & soón & soóṇ & soná & sóoṇ & no data \\
\hline 281. gun & tumák & țubák & tumák, tubák & tumák & tumák & no data \\
\hline 282. hedgehog & - & - & - & šãấti & žukúl & no data \\
\hline 283. heel & khúuri & thúri & thúri & khirkáli & thúri & no data \\
\hline 284. lamb & urán & mamtoó & urán & urán & urán & no data \\
\hline 285. leopard & $\mathrm{d} \tilde{\overline{1}}$ & dî́ & dĩu, dhĩi & dî̃ & dhĩ̃ & no data \\
\hline 286. Milky Way & balajé $^{8}$ & bólaj & balãjée & no data & táaro ałấi & no data \\
\hline 287. mirror & eéno, gayuúri & mukcáaki & šiišá & šiišá & šiišá & no data \\
\hline 288. nut & khakáaĩ & $\begin{array}{l}\text { khakái, } \\
\text { gayáa }\end{array}$ & gayáa & no data & açhoó, káli & no data \\
\hline
\end{tabular}

8 Also: ã̌špo-ga dóney pon, 'path of the horse and bull'. 
TABLE 2: COMPARATIVE SHINA VOCABULARIES

\begin{tabular}{|c|c|c|c|c|c|c|}
\hline Gloss & $\underline{\text { Gilgiti }}$ & $\underline{\text { Kohistani }}$ & Guresi & Astori & $\underline{\text { Drasi }}$ & $\underline{\text { Brokskat }}$ \\
\hline 289. palm of hand & háta táawo & hattóo & hatatáa & hattáao & hattáa & no data \\
\hline 290. rainbow & bijoón, biẓoón & biẓoón & bijoóni & bijoón & bizoóni & no data \\
\hline 291. rice (paddy) & brî́w & byũ, talúụ & dayố & briứ & dayốõ & no data \\
\hline 292. rice (cooked) & bat & baát & bríim, bái & baát & brim & no data \\
\hline 293. scorpion & karaáțo 9 & laṛám & bic & junumáaro & bic & no data \\
\hline 294. shame & laš, šarm & šarám & laš & be šarm & šarm, laš & no data \\
\hline 295. sleep & nir & níiș & níiș & níiṣ & nีĩ̄ṣ & no data \\
\hline 296. spleen & šóom & šóom & šóom & no data & šóom & no data \\
\hline 297. to write & likhoók & likoón & likhyoónu & likhoónu & likhyoónu & no data \\
\hline
\end{tabular}

9 This may mean 'poisonous spider'. Scorpions are not found in Gilgit. 
TABLE 3: COMPARATIVE KASHMIRI VOCABULARIES

Stress on first syllable unless otherwise noted. $\hat{v}=$ a rising tone; $\check{v}=$ a low rising tone.

Gloss $\underline{\text { Kashmiri }}$

$\underline{\text { Kishtawari }}$

$\underline{\text { Poguli }}$

$\underline{\text { Siraji }}$

I. Body parts

1. armpit

kats $^{\mathrm{h}}$

2. beard

3. belly

do:r

yad

4. blood

$\mathrm{rat}^{\mathrm{h}}$

5. bone

6. brain

7. breast

aḍidž

8. ear

9. elbow

10. eye

11. face

12. finger

13. fingernail

di'ma: $\dot{g}^{1}$

mami

kan

$\mathrm{k}^{\mathrm{h}}$ oniwat ${ }^{\mathrm{h}}$

$\partial c^{\mathrm{h}}$

but ${ }^{\text {h }}$

ongidž

nam

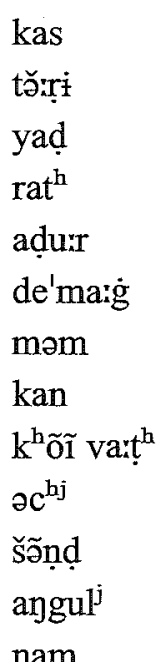

kats $^{\mathrm{h}}$

dərr

isd

$\mathrm{rat}^{\mathrm{h}}$

aḍlje

de'maig

sina

kan

thon $^{\mathrm{j}} \mathrm{u} \mathrm{wart}^{\mathrm{h}}$

aš

dik

anglje

nam

1 According to Wali and Koul 1997: 307, Kashmiri is a syllable-timed language, and stress is not distinctive. When non-initial, it is marked in this transcription on items 1-197, which have been transcribed from recorded data, but not on items 198-267, which are taken from written sources using phonemic transcription. 
$\underline{\text { Gloss }}$

14. flesh

15. foot

16. hair

17. hand

18. head

19. heart

20. kidney

21. knee

22. lip

23. liver

24. moustache

25 . mouth

26. neck

27. nose

28. skin

29. shoulder

Stress on first syllable unless otherwise noted. $\dot{V}=$ a rising tone; $\check{V}=$ a low rising tone.

\begin{tabular}{|c|c|c|c|}
\hline Kashmiri & $\underline{\text { Kishtawari }}$ & Poguli & $\underline{\text { Siraji }}$ \\
\hline ma:z & ma:z & mazz & ma:s \\
\hline $\mathrm{k}^{\mathrm{h}}$ or & $\mathrm{k}^{\mathrm{h}} \mathrm{or}$ & $\mathrm{k}^{\mathrm{h}} \mathrm{ur}$ & $\mathrm{k}^{\mathrm{h}}$ or \\
\hline mas & varl, tsont & masti & $\mathrm{zu}^{\mathbf{l}}$ to \\
\hline athi & athi & a:ht & hat \\
\hline kali & $\operatorname{šitr}^{\mathrm{j}}$ & lot & rot \\
\hline dil & dil & dil & dil \\
\hline bokiwat ${ }^{\text {h }}$ & gur'di & buk $^{\mathrm{h}}$ & $\operatorname{gur}^{\mathrm{I}} \mathrm{da}$ \\
\hline kot $^{\mathrm{h}}$ & $\operatorname{kot}^{\mathrm{h}}$ & $\operatorname{kut}^{\mathrm{h}} \mathrm{e}$ & $\mathrm{kut}^{\mathrm{h}}$ \\
\hline vut ${ }^{\text {h }}$ & $u t^{\mathrm{h}}$ & lemur & hort \\
\hline krəhni ma:z & ka'ledža & $\mathrm{k}^{\mathrm{j}} \mathrm{a}: \mathrm{liz}$ & kail'zo \\
\hline gorə̃ts & kŏ̃tsi & $\operatorname{guc}^{\mathrm{h}} \mathrm{e}$ & $\mathrm{muc}^{\mathrm{h}}$ \\
\hline$\partial x \mathrm{~S}$ & $2: s^{j}$ & mo'ix & arsi \\
\hline gardan & gar'dan & gar'dun, mat $^{\mathrm{h}}$ & mũṇđi \\
\hline nas & nas & narht & nak \\
\hline mislì & musli & tsam, $\mathrm{n}^{\mathfrak{j}} \mathrm{a}: \mathrm{l}$ & niyarli \\
\hline $\mathrm{p}^{\mathrm{hj}} \mathrm{ok}$ & šok & $\mathrm{nak}^{\mathrm{h}}$ & $\mathrm{p}^{\mathrm{h}} \mathrm{ak}^{\mathrm{\prime}} \mathrm{k}$ \\
\hline
\end{tabular}


TABLE 3: COMPARATIVE KASHMIRI VOCABULARIES

Stress on first syllable unless otherwise noted. $\bar{V}=$ a rising tone; $\check{V}=$ a low rising tone.

\begin{tabular}{|c|c|c|c|c|}
\hline$\underline{\text { Gloss }}$ & $\underline{\text { Kashmiri }}$ & $\underline{\text { Kishtawari }}$ & Poguli & $\underline{\text { Siraji }}$ \\
\hline 30. thumb & $\mathrm{n}^{\mathrm{j}} \mathrm{ot} \underline{\mathrm{h}}^{\mathrm{h}}$ & not ${ }^{\mathrm{h}}$ & $\mathrm{n}^{\mathrm{j}} \partial \underline{!}^{\mathrm{h}}$ & not \\
\hline 31. tongue & $z^{\mathrm{j}} \mathrm{au}$ & $z^{\mathrm{j}} \mathrm{au}$ & celba:n, $z^{j}$ eu & $\mathrm{zib}$ \\
\hline 32. tooth & dand & dãd & dãt & dãnt \\
\hline 33. urine & mithir & muthir & muc & mu'tar \\
\hline \multicolumn{5}{|c|}{ II. Terms for kin and human beings } \\
\hline 34. brother & bo:y & pǒry & barrun & bráru \\
\hline 35. brother's wife & bəy ka:kin & pă: $b^{j}$ & ka:kin & bar'džá:i \\
\hline 36. daughter & kurr & kuri ${ }^{j}$ & kur $^{\mathrm{j}}$ & rẽ'ți: \\
\hline 37. daughter-in-law & nəš & noš & nuh & nuš \\
\hline 38. father & mo:1 & mǒll & mo:əl, bo:əb & ba:bo \\
\hline 39. father's brother & $\mathrm{p}^{\mathrm{j} \partial \mathrm{tir}}$ & carci & pi'cau & $\begin{array}{l}\text { nikro barbo, } \\
\text { baḍo barbo }\end{array}$ \\
\hline 40. father-in-law & $\mathrm{h}^{\mathrm{j}}$ ohur & yă:r & ša'hur & šurro \\
\hline 41. granddaughter & potir & pur'tir & poratri & po:tri, dhiyo:'ri: \\
\hline 42. grandson & potur & pur'tur & porutru & po:tro, dhiyo:'ro: \\
\hline 43. mother & mərdž & mă:l & məæ:1 & mai'li: \\
\hline
\end{tabular}


Stress on first syllable unless otherwise noted. $\hat{V}=$ a rising tone; $\check{V}=$ a low rising tone.

Gloss

44. mother's brother

45. mother-in-law

46. sister

47. son

48. son-in-law

49. wife's brother

50. child

51. man

52. name

53. person

54. woman

\section{Human artifacts}

55. arrow

56. ashes

57. bed

58. bread

\section{Kashmiri}

marm
haš
beni
necu
zarmtur
həhar
šur
marid
na:o
in'sa:n, a:dam
ze'na:n

ti:r

su:r

pa'lan, carrpari

tsot $\underline{\text { Kishtawari }}$

ma:əm
a:š
did
bo'kut
za'motur
sa:li
bacì
mo:n
na:m
mə̃̃̃
ze'na:n mã̃

ti:r

swais

$\mathrm{k}^{\mathrm{h}} \mathrm{at} \mathrm{t}^{\mathrm{h}}$

mãndž $\underline{\text { Poguli }}$

ma:əm

šah

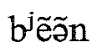

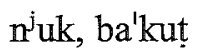

zamotru

sa:le

$\mathrm{n}^{\mathrm{j} u k}$

ma'hun

na:m

mard

kur nahi'ni

tirr

swars, swa:h

$\mathrm{k}^{\mathrm{h}}$ at

mẽṇ̃ $\underline{\text { Siraji }}$

mam'mõ

šaš

bein ma ${ }^{\mathrm{t}} \mathrm{t}^{\mathrm{h}} \mathrm{o}$ : džama'tro: sailo, be:i'mo mat $t^{\mathrm{h}}$ : mard nã:m ma:'nũ: ze'na:n

tír swa:h $\mathrm{k}^{\mathrm{h}}$ ati ro'ti: 
TABLE 3: COMPARATIVE KASHMIRI VOCABULARIES

Stress on first syllable unless otherwise noted. $\bar{V}=$ a rising tone; $\check{V}=$ a low rising tone.

\begin{tabular}{|c|c|c|c|c|}
\hline$\underline{\text { Gloss }}$ & Kashmiri & Kishtawari & Poguli & $\underline{\text { Siraji }}$ \\
\hline 59. churn & do:ən, $c^{\mathrm{h}} \mathrm{o}: \tilde{p} \mathrm{p}$ & $c^{\mathrm{h}}$ orp & $\mathrm{ma}^{\prime} \mathrm{d}^{\mathrm{h}} \tilde{\mathfrak{x}} \mathrm{n}, \mathrm{c}^{\mathrm{h}} \mathrm{op}$ & $c^{\text {h }} \tilde{a}: m p w ə$ \\
\hline 60. curds & za:mut dwad & daĩ & zam dud & zam'ro dudi \\
\hline 61. dream & sopun, xwa:b & sopan & $\mathrm{k}^{\mathrm{h}} \mathrm{wa:b}$ & semi'ṇõ \\
\hline 62. fertilizer & pah & păma & gun & híll \\
\hline 63. field & $\mathrm{k}^{\mathrm{h}} \mathrm{ah}$, dal & $\operatorname{vodžj~}^{j}$ & væigə & ba'gi: \\
\hline 64. fire & na:r & nair & narr & agi \\
\hline 65. ghee & $\mathrm{g}^{\mathrm{j}} \mathrm{au}$ & kjău & $\mathrm{g}^{\mathrm{j}} \mathrm{u}:$ & gyu: \\
\hline 66. grease & car'bi:h & $t^{j}$ op & car'bi: & mẽz \\
\hline 67. handspan & asti & paru & bithi & griți \\
\hline 68. honey & ma:ch & mã:ch & mæ:ch & marchi: \\
\hline 69. house & gari & kări & gor & gar \\
\hline 70. irrigation channel & yan, kol & koi & la:b & kulə \\
\hline 71. loom & va:n & va:n & varn & $\mathrm{k}^{\mathrm{h}} \mathrm{addi}$ \\
\hline 72. mattock (hoe) & billci & $\mathrm{d} ə \mathbf{l}^{\mathrm{j}}$ & no data & də:li \\
\hline 73. milk & dwad & dwad & dud & dudi \\
\hline 74. path & vat $^{\text {h }}$ & $\mathrm{vat}^{\mathrm{h}}$ & vat $^{\text {h }}$ & ba:t'ti: \\
\hline 75. plow & arli & a:li & $\mathrm{al}$ & hali \\
\hline
\end{tabular}


Stress on first syllable unless otherwise noted. $\bar{V}=$ a rising tone; $\check{V}=$ a low rising tone.

\section{$\underline{\text { Gloss }}$}

76. roof

77. salt

78. sickle

79. smoke

80. spinning wheel

81. village

82. wood

83. work

N. The sky, weather

84. blue sky

85. cloud

86. lightning

87. moon

88. rain

89. sky

90. snow

\section{Kashmiri}

paš

nu:n

dro:ət

dih

yãndìr

ga:m

$z^{j}$ un

kərm

$n^{j} u: 1$ as'ma:n
obur
vuzmal
zu:n
ru:d
as'ma:n
šin

\section{$\underline{\text { Kishtawari }}$}

lǒ:

luin

dro:t

tǔ:m

yãndir

gã:m

tsuri $]^{j}$

karr

ño:l as'ma:n
abar
tsapkĩ
zo:'san
ru:d
as'ma:n
šinn

Poguli

$\mathrm{c}^{\mathrm{h}}$ at

nu:n

darch

dusom

yandiri

garm

kait ${ }^{\text {h }} \mathrm{e}$

ka:r

ñuil as'ma:n $_{\text {paḍ }}$
bidžli
tsandirł
ro:ət
as'ma:n
šiìn

$\underline{\text { Siraji }}$

la'ro:

lự

no data

dú:m

džãn'tar

gra:m

ka: $t^{\text {h }}$ a, tso:ri'ya

kammə

ni:lo a'mar

badə'lo

uzmuli'ya

ca:'ni:

dero:

a'mar

hím 
TABLE 3: COMPARATIVE KASHMIRI VOCABULARIES

Stress on first syllable unless otherwise noted. $\bar{v}=$ a rising tone; $\check{v}=$ a low rising tone.

\begin{tabular}{|c|c|c|c|c|}
\hline & & & & \\
\hline Gloss & $\underline{\text { Kashmiri }}$ & $\underline{\text { Kishtawari }}$ & $\underline{\text { Poguli }}$ & $\underline{\text { Siraji }}$ \\
\hline 91. star & tarrux & tor & tarrgan & ta:'ro: \\
\hline 92. sun & si'ri, af'ta:b & do:s & duss & $\operatorname{dits}$ \\
\hline 93. water & po:ən $n^{j}, a \cdot b$ & pã:ĩ & paẽ & paṇi \\
\hline 94. wind & havai, vaiu & vau & hawa, ts $\mathrm{s}^{\mathrm{h}_{\mathrm{at}}}$ & bá:t ${ }^{\mathrm{h}}$ \\
\hline V. Time and spac & & & & \\
\hline 95. afternoon & pešin, digar & do:s'le & dusli ba:d & byarli ku'ṇo \\
\hline 96. autumn & harud & šæ:r ka:l & panti & še:T \\
\hline 97. day & doh & do:s'le & duss & diya:'ṛi: \\
\hline 97a. Saturday & baț(i) varr & šæ̃cir va:r & no data & šã'cal \\
\hline 97b. Sunday & $\mathrm{a}: \mathrm{t}^{\mathrm{h}}$ varr & $æ: t^{\mathrm{h}}$ varr & no data & $\mathrm{a}: \mathrm{t}^{\mathrm{h}}$ \\
\hline 97c. Monday & tsandir varr & tsandir va:r & no data & tsan'dar \\
\hline 97d. Tuesday & bõ: va:r & mangal va:r & no data & maj'gal \\
\hline 97e. Wednesday & bod(u) va:r & bod varr & no data & bodi \\
\hline 97f. Thursday & bres varr & brest varr & no data & bre'fati \\
\hline 97g. Friday & džumah & šukir var & no data & šu'kar \\
\hline
\end{tabular}


Stress on first syllable unless otherwise noted. $\bar{V}=$ a rising tone; $\check{V}=$ a low rising tone.

98. day after tomorrow 99. down(hill)

100. east

101. evening

102. month

102a. Vaisakha

102b. Jestha

102c. Asadh

102d. Sravan

102e. Bhadra

102f. Ashvina

102g. Kartika

102h. Marga

102i. Pausha

102j. Magha

Kashmiri

$\underline{\text { Kishtawari }}$

$\underline{\text { Poguli }}$

$\underline{\text { Siraji }}$

kə: $^{j}$ ket $^{\mathrm{h}}$
bon
purr, mašrik
šarmi, šarm
no data
vaihek
zerot ${ }^{\mathrm{h}}$
harr
šra:vun
bərdir pat $^{\mathrm{j}}{ }^{\mathrm{h}}$
əsurdž
kartik
magar
poh
ma:g

tre do:s
bon pa:ras kin
purrəb
kwali
no data
və'ša:k
zerə!
ărr
šra:van
pă:drət
a:šət
karrtik
ma:džar
poh
ma:g

cindis
ba:lus $\mathrm{k}^{\mathrm{h}} \mathrm{al}$
mašrik
varnł
no data
no data
no data
no data
no data
no data
no data
no data
no data

țẽ:'tsẽ

o'ro:

tsarnì tín ${ }^{-1}$ ãti

biya:'lo:

no data

bi '̌̌a:k ${ }^{h}$

dže:t ${ }^{\mathrm{t}}$

hiľ̌a:r

šro:n

$b^{\mathrm{h}} \mathrm{a}: \mathrm{i} d r o$

ə’šurdž

ka:t'ti:

mo'girr

pa:' $p^{h_{i}}$

dar'mi: 
TABLE 3: COMPARATIVE KASHMIRI VOCABULARIES

Stress on first syllable unless otherwise noted. $\bar{V}=$ a rising tone; $\breve{v}=$ a low rising tone.

\begin{tabular}{|c|c|c|c|c|}
\hline Gloss & Kashmiri & Kishtawari & Poguli & $\underline{\text { Siraji }}$ \\
\hline 102k. Phalguna & $\mathrm{p}^{\mathrm{h}}$ a:gun & $\mathrm{p}^{\mathrm{h}}$ arrgun & no data & $\mathrm{p}^{\mathrm{h}} \mathrm{a}:$ 'gun \\
\hline 1021. Chaitra & $\mathrm{tsit}^{\mathrm{h}} \mathrm{ir}$ & tsit $^{\mathrm{h}} \dot{\mathrm{ir}}$ & & tsit ${ }^{b} a r$ \\
\hline 103. morning & $\operatorname{sub}^{\mathrm{h}} \mathrm{ai}$ & ig'ri: & $\operatorname{rec}^{\mathrm{h}_{\mathrm{i}}}$ & o:'tre \\
\hline 104. night & $\operatorname{rat}^{\mathrm{h}}$ & rarti & rait & ra: ti \\
\hline 105. sunny side of & & & & \\
\hline mountain & - & - & dašno & da'lã tił'wãati \\
\hline $\begin{array}{l}\text { 106. shady side of } \\
\text { mountain }\end{array}$ & - & - & $\mathrm{k}^{\mathrm{h}}$ auru & tsarnì tín ${ }^{\prime} w a ̃ a t i$ \\
\hline 107. seasonal & & & & \\
\hline migration & na:i gatsmuk waxit & ret ka:l & $a^{\prime} d^{b} æ r r$ & retu:'rọo \\
\hline 108. spring (season) & sõ:t ka:l & sõṭ ka:1 & ba'ha:r & ne:'la: \\
\hline 109. summer & ret ko:l & ret ka:l & garma & retu:'rọo \\
\hline 110. today & $a z$ & az & aiz & $\operatorname{adti}$ \\
\hline 111. up(hill) & pet $^{\mathrm{h}}$ & pet $^{\mathrm{h}}$ parras kin & ma:l & $\mathrm{k}^{\mathrm{h}} \mathrm{a}^{\prime}$ ro: \\
\hline 112. west & qibli, pašim, mağrib & pascim & magrib & ma'grib \\
\hline 113. winter & vandi & $\mathrm{pa \tilde {a }} d \dot{\mathrm{z}}$ & bãnd & hindi \\
\hline 114. year & vəri: & $\mathrm{p}^{\mathrm{h}}$ uri: & veh, ver & ba'ri: \\
\hline
\end{tabular}


TABLE 3: COMPARATIVE KASHMIRI VOCABULARIES

Stress on first syllable unless otherwise noted. $\dot{V}=$ a rising tone; $\check{v}=$ a low rising tone.

Gloss

$$
\underline{\text { Kashmiri }}
$$

$\underline{\text { Kishtawari }}$

$\underline{\text { Poguli }}$

$\underline{\text { Siraji }}$

VI. Earth

115. earth

116. earthquake

$\begin{array}{ll}\text { zə'minn } & \text { zə'mi:n } \\ \text { bunjul } & \text { pǔ'mil } \\ \text { džangal } & \text { van }\end{array}$

117. forest

118. highest summer pasture

119. hill

120. mountain

121. river

122. sand

nari, niurr

tăạ

țẽ̃’วng

tob

bail, pa'har, koh

dor'yau

$\mathrm{s}^{\mathrm{j} a k^{\mathrm{h}}}$

păṛ̣

dər'yaiu

re:t

na:g

123. spring (of water)

124. stone

$\mathrm{kən}^{\mathrm{j}}$

$k^{\mathrm{h}}$ orr, rwãd

rexi

$\mathrm{k}^{\mathrm{h}} \mathrm{ar}$

125. ant

126. ass

127. bear

harput

bi'di:l

$\mathrm{k}^{\mathrm{h}} \mathrm{o}: \mathrm{ta}$

a:pət

ze'min

bum tsal

de'mĩ:

bõ'tsal

dzarr

van

adu'varr

cargarna

no data

pa'har

dar'yau

re:t

na:g

narg

gorr

ru:ṇdi

bid'li:

krimni

$\mathrm{k}^{\mathrm{h}} \mathrm{x}^{\prime}$ to

$\mathrm{k}^{\mathrm{h}} \mathrm{ar}$

ich 
TABLE 3: COMPARATIVE KASHMIRI VOCABULARIES

Stress on first syllable unless otherwise noted. $\tilde{v}=$ a rising tone; $\check{v}=$ a low rising tone

\begin{tabular}{|c|c|c|c|c|}
\hline Gloss & Kashmiri & $\underline{\text { Kishtawari }}$ & Poguli & $\underline{\text { Siraji }}$ \\
\hline 128. bird & dža:nvar, dža:narva:r & pa'rindi & pa'rində & pak $^{\mathrm{hl}}$ nũ: \\
\hline 129. bull & da:nd & dã:t & dã:nt & dã:nt \\
\hline 130. bumblebee & bombur & tĩ̌:d & $b^{h_{2} u m u r}$ & $\mathrm{~b}^{\mathrm{h}} \tilde{\mathrm{o}}: \mathrm{I}^{\prime} \mathbf{r o}$ \\
\hline 131. cat $m$. & bro:r & bro:rr & brast & bila:'rux \\
\hline 132. cat $f$. & bra:r & broxt $^{j}$ & bræṛ & bila:'ṛi: \\
\hline 133. crow & kau & kau & karu & káu \\
\hline 134. cow & garu & garu & gaũ & $\mathrm{ba}^{\prime} \mathrm{ts}^{\mathrm{h}_{\mathrm{ii}}}$ \\
\hline 135. dog & hu:n & u:n & hun & šũ'ṇa: \\
\hline 136. egg & thuil & thuu:1 & tho:l & thúil \\
\hline 137. feather & $\mathrm{pak}^{\mathrm{h}}$ & $\operatorname{pak}^{\mathrm{h}}$ & pãhț & $\mathrm{pak}^{\mathrm{h}}$ \\
\hline 138. fish & garr & gard & ga:rị & $\operatorname{mac}^{\mathrm{h} \prime} 1 \mathrm{i}:$ \\
\hline 139. flea & $\mathrm{p}^{\mathrm{j}} \mathrm{uš}$ & $\mathrm{p}^{\mathrm{j}} \mathrm{uš}$ & $\mathrm{p}^{\mathrm{j} u h}$ & pri: 'šu: \\
\hline 140. goat $m$. & tsarvul & síl $^{1} d u i l$ & kațlo & twait ${ }^{\mathrm{h}}$, tse $l u$ \\
\hline 141. goat $f$. & tsa:vidž & $\operatorname{sil} i^{\mathrm{j}}$ & $\mathrm{ts}^{\mathrm{h}} \mathrm{el}$ & bak'ri: \\
\hline 142. hen & kokir & $\mathrm{ku}^{\prime} \mathrm{kir}^{\mathrm{j}}$ & kuk'rix & kuki'rịi: \\
\hline 143. horn & hen & hin & hing & šingə \\
\hline 144. horse & gur & kǒr & $\mathrm{g}^{\mathrm{h}} \mathrm{Or}$ & $\mathrm{g}^{\mathrm{h}} \mathrm{o}:$ 'ro \\
\hline
\end{tabular}


TABLE 3: COMPARATIVE KASHMIII VOCABULARIES

Stress on first syllable unless otherwise noted. $\hat{V}=$ a rising tone; $\check{v}=$ a low rising tone.

Gloss

145. louse

146. louse (nit)

147. mouse, rat

148. rooster

149. sheep

149a. ewe

149b. ram

150. snake

151. tail

152. wasp

\section{Kashmiri}

zou

lic $\mathrm{c}^{\mathrm{h}}$

$\mathrm{k}^{\mathrm{h}} \mathrm{rõ}: t s$, gagir

ko:kor

tirr $^{j}$

gəb

kat ${ }^{\text {h }}$

saruf

lot

tulìr, datìr $\underline{\text { Kishtawari }}$

tsõ:i

$\operatorname{lic}^{\mathrm{h}}$

ga'gər

kokər

gəbiz, tirr ${ }^{j}$

gəbiz

gəbur

sa'rap $^{\mathrm{h}}$

põrsir

tsrä:ặ: $1^{j}$
Poguli

zo:e

$\mathrm{d}^{\mathrm{h}}$ ak

gagri

ku'kur

$\mathrm{g}^{\mathrm{j}} \mathrm{eb}$

lao

$\mathrm{g}^{\mathrm{j}} \mathrm{eb}$

sarap $^{\mathrm{h}}$

let

cum'hæ̃:r $\underline{\text { Siraji }}$

džũ:

$\operatorname{lic}^{\mathrm{h}}$

muštnũ:

ku'kar

$\mathbf{b}^{\mathrm{h}}$ eḍ̣

b eḍ̣̂e:

$b^{\mathrm{h}}$ edọtu:

sappi

lenañi

trim'rị:

trãndi'ha:l

se:o

$\mathrm{k}^{\mathrm{h}} \mathrm{oba}$ 'ni

šo'kar

džoru

VIII. The plant word

153. apple

tsũ:t ${ }^{\mathrm{h}}$

tsư:t th $^{\text {h }}$

154. apricot

tse:r

155. bark (of tree)

del

$\mathrm{k}^{\mathrm{h}} \mathrm{o}^{\prime}$ ba:n

tsoh

batsir

156. barley

viški

$\mathrm{d}^{\mathrm{j} a l}$

$\mathrm{d}^{\mathrm{H}} \mathrm{il}$

dža'war 
TABLE 3: COMPARATIVE KASHMIRI VOCABULARIES

Stress on first syllable unless otherwise noted. $\hat{v}=$ a rising tone; $\check{V}=$ a low rising tone.

\begin{tabular}{|c|c|c|c|c|}
\hline Gloss & Kashmiri & Kishtawari & Poguli & Siraji \\
\hline 157. birch & burzu kul & dạl & rayil & da:'li: \\
\hline 158. cedar & diovdarr & djo'dart & d'ov'da:r & di'ya:r \\
\hline 159. fig (fruit) & an'džirr & $\mathrm{p}^{\mathrm{h}} \mathrm{O}: \mathrm{g}$ & $p^{h}$ org & an'džjir \\
\hline 160. grape(s) & $\mathrm{dac}^{\mathrm{h}}$ & no data & $\mathrm{dac}^{\mathrm{h}}$ & no data \\
\hline 161. grass/fodder & garsi, $\mathrm{kac}^{\mathrm{h}}$ & kă:si & gз:2s & $\mathrm{g}^{\mathrm{h} a ́ r s}$ \\
\hline 162. leaf & panivatir & patar & patiri & pat'tar \\
\hline 163. maize & ma'kəii & kok'ṛe & ma'kai & kukarii'ya \\
\hline 164. mulberry tree & tul kul & tul kul & tul & tutta də buța \\
\hline 165. pomegranate & də:n & də:n & darịim & a'na:r, dar'mo:li \\
\hline 166. poplar & fras & frast kul & phrasti $\mathrm{k}^{\mathrm{w}} \mathrm{ul}$ & safe:'do: \\
\hline 167. root & mu:l & zi:l & mu:l & dei:l \\
\hline 168. seed & $b^{j} o_{1}$ & $b^{j} o_{0} l$ & $b^{j} 0: 1$ & bidžว \\
\hline 169. tree & kul & kul & kwala & buțə \\
\hline 170. walnut & du:n $n^{j}$ & churr & ochur & acho:l \\
\hline 171. willow & vir & yirt & yer $\mathrm{k}^{\mathrm{w}} \mathrm{ul}$ & be:di də buța \\
\hline
\end{tabular}




\section{$\underline{\text { Gloss }}$}

LX. Verbs

172. to beat

173. to bite

174. to burn $i$.

175. to burn $t$.

176. to come

177. to cry

178. to die

179. to drink

180. to eat

181. to fly

182. to give

183. to go

184. to harvest

185. to hear

186. to kill

Stress on first syllable unless otherwise noted. $\hat{v}=$ a rising tone; $\check{v}=$ a low rising tone.

$\underline{\text { Kashmiri }}$

$\begin{array}{ll}\text { la:yun } & \mathrm{c}^{\mathrm{b}} \text { o:b din } \\ \text { tsop hjon } & \text { tsop koron } \\ \text { dazun } & \text { dazun } \\ \text { za:lun } & \text { za:lun } \\ \text { yuin } & \text { yuin } \\ \text { vadun hion, vadun } & \text { ru:n } \\ \text { marun } & \text { marun } \\ \text { con } & \text { con } \\ \mathrm{k}^{\mathrm{hj}} \text { on } & \mathrm{k}^{\mathrm{hj}} \text { on } \\ \text { vudun } & \text { udun } \\ \mathrm{d}^{\mathrm{j}} \text { un } & \text { diun } \\ \text { gatsun } & \text { gatsun } \\ \text { lo:nun } & \text { lo:nun } \\ \text { bo:zun } & \text { bo:zun } \\ \text { ma:run } & \text { ma:run }\end{array}$

$\underline{\text { Poguli }}$

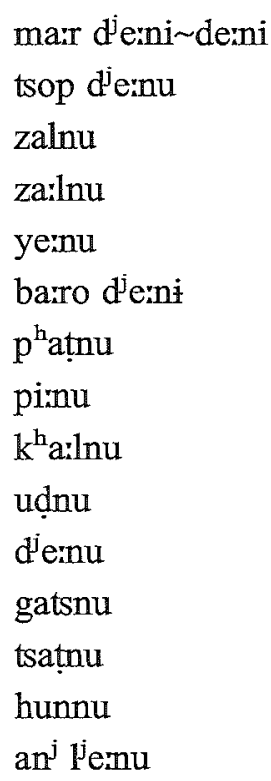

$\underline{\text { Siraji }}$

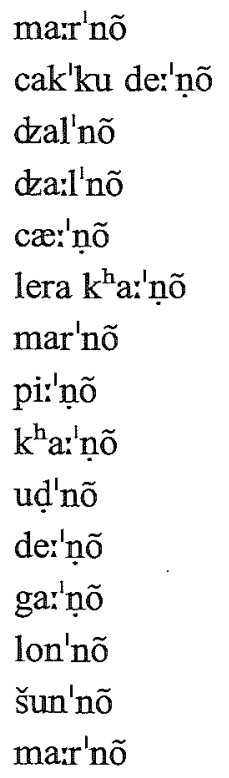


TABLE 3: COMPARATIVE KASHMIRI VOCABULARIES

Stress on first syllable unless otherwise noted, $\hat{v}=$ a rising tone; $\check{v}=$ a low rising tone.

\begin{tabular}{|c|c|c|c|c|}
\hline Gloss & Kashmiri & $\underline{\text { Kishtawari }}$ & Poguli & $\underline{\text { Siraji }}$ \\
\hline 187. to know & za:nun & za:nun & za:nnu & dza:ṇ'ṇõ \\
\hline 188. to laugh & asun & ãsun & hasnu & has'nõ \\
\hline 189. to lie (down) & da:f trarvun & da:f tra:vin & šũynu & deul'nõ \\
\hline 190. to say & vanun & zabun & vannu & dz:'ṇõ \\
\hline 191. to see & $\operatorname{vvuc}^{\mathrm{h}}$ un & $\mathrm{uc}^{\mathrm{h}} \mathrm{un}$ & ba:lnu & her'nõ \\
\hline 192. to sit & bih'un & $b^{j}$ un & bimnu & biš'nõ \\
\hline 193. to sleep & šanun & šopun & šũynu & deul'nõ \\
\hline 194. to stand & thod vot ${ }^{\mathrm{h}}$ un & oši vatun & $\begin{array}{l}\text { thod uthnu, } \\
\mathrm{k}^{\mathrm{h}} \text { ar hunu }\end{array}$ & $\mathrm{k}^{\mathrm{h}} \operatorname{arost}^{\mathrm{h}}{ }^{\mathrm{l}} \mathrm{no}$ \\
\hline 195. to swim & tsã:ț va:in & $\mathrm{t}^{\mathrm{j}}$ orun & t3:ər $d^{j} e: n^{j} \dot{i}$ & $\operatorname{tar}^{\prime}$ กõ \\
\hline 196. to walk & $\operatorname{pak}^{\mathrm{h}} \mathrm{un}$ & $\tilde{o}^{\mathrm{h}} u$ un & $c^{\text {halnu }}$ & cal'nõ \\
\hline 197. to wash $t$. & $c^{\mathrm{b}_{\text {alun }}}$ & $c^{h}$ alun & $\mathrm{d}^{\mathrm{h}}$ aunu & $c^{h}$ al'nõ \\
\hline \multicolumn{5}{|l|}{$X$ Adjectives } \\
\hline 198. all (sārā) & sərri: ${ }^{2}$ & sori: & sor & sa:'re \\
\hline
\end{tabular}

2 The Kashmiri word list was incomplete, and items 198-267 have been filled in from the following two sources: Wali and Koul 1997 (especially 5.2), and Kachru 1973, Vol. 2 (Glossary). 
TABLE 3: COMPARATIVE KASHMIRI VOCABULARIES

Stress on first syllable unless otherwise noted. $\hat{V}=$ a rising tone; $\check{V}=$ a low rising tone.

$\underline{\text { Gloss }}$

199. all (sab)

200. big

201. bitter

202. black

203. blind

204. cold

205. dry

206. eight

207. eighteen

208. eleven

209. few

210. fifteen

211. five

212. forty-one

213. four

214. fourteen

\section{$\underline{\text { Kashmiri }}$}

kul

bod

no data

kruhun

no data

tìr

$\mathrm{k}^{\mathrm{h}}$ ošik $\mathrm{k}^{\mathrm{h}}$

oit

ardah

$\mathrm{kah}$

kẽh

pandah

pã:ts ${ }^{\text {h }}$

akita:džih

tso:r

tso'dah $\underline{\text { Kishtawari }}$

soru'wi:

bod

tjot $^{\mathrm{b}}$

krišun

ko:ṇ

thã th

huk $^{\text {h }}$

exot ${ }^{\mathrm{h}}$

ar'dah

kah

$k^{j} \tilde{\mathrm{e}}$

pan'dah

pãts ${ }^{\text {h }}$

ak tarlih

tso:T

tso'dah $\underline{\text { Poguli }}$

sor'wi:

bor

tsihțu

krihnu

on

turr

huk $^{\mathrm{h}}$

arht

ar'dah

kah

kĩits

pas'tah

pãits

yak ta:lih

tsaiwar

tso'dah $\underline{\text { Siraji }}$

mat'te:

ba'ḍo:

ko:'ro:

ka:'lo:

ka:'no:

thã'do:

šuk'ro:

$\mathrm{at}^{\mathrm{h}}$

at ${ }^{\mathrm{h}} \mathrm{a} \mathbf{i}^{\prime} \mathrm{ra}$

ya:'ra:

ke:

pan'dra:

pãts ${ }^{\mathrm{h}}$

ikta:'li:

tsurr

tsa:'li: 
TABLE 3: COMPARATIVE KASHMIRI VOCABULARIES

Stress on first syllable unless otherwise noted. $\bar{v}=$ a rising tone; $\check{V}=$ a low rising tone.

\begin{tabular}{|c|c|c|c|c|}
\hline Gloss & Kashmiri & Kishtawari & Poguli & $\underline{\text { Siraji }}$ \\
\hline 215. full & bərit $^{\mathrm{h}}$, purri & par'ye:ət $^{\text {h }}$ & $b^{h_{e}}$ & $\mathrm{~b}^{\mathrm{h}}$ au'ro: \\
\hline 216. good & dža:n & džaan & laryex & ro'lo: \\
\hline 217. green & sabizz & $\mathrm{n}^{j} \mathrm{u}: 1$ & sabzi & ni:lo: \\
\hline 218. hot & tot, garim & tot & garmə & tat'to: \\
\hline 219. hundred & $\mathrm{hat}^{\mathrm{h}}, \mathrm{šat}^{\mathrm{h}}$ & $\mathrm{hat}^{\mathrm{h}}$ & hathi & šou \\
\hline 220. hungry & no data & $\operatorname{poc}^{\mathrm{h} /} w i$ & bu:ch & buc'co: \\
\hline 221. left (direction) & $\mathrm{k}^{\mathrm{b}}$ orvur & $\mathrm{k}^{\mathrm{h}}$ orvur & no data & ba:'mẽ: \\
\hline 222. long & $z^{\mathrm{j} u} \mathrm{t}^{\mathrm{h}}$ & lambi & zehtu & lam'mõ: \\
\hline 223. many & varriyah & varriyah & $z^{j} a: d i$ & mat'te: \\
\hline 224. new & nov & nau & nau & na'vo \\
\hline 225. nine & nav & naũ & กãã & nao \\
\hline 226. nineteen & kunivuh & kunnõ & kun'vih & un'ni: \\
\hline 227. old (person) & buḍi & buḍi & bud ${ }^{\mathrm{h}}$ & bu'do: \\
\hline 228. one & $\mathrm{ak}^{\mathrm{h}}$ & $\mathrm{ek}^{\mathrm{h}}$ & yah & ekə \\
\hline 229. red & vozul & la:l & uzlu & la:l \\
\hline 230. right (direction) & $d c^{h_{1}}$ un & $d ə c^{h} u n$ & daš niš & dæ'ṇ̃o: \\
\hline 231. round & go:l & go:l & go:ol & go:l \\
\hline
\end{tabular}


TABLE 3: COMPARATIVE KASHMIRI VOCABULARIES

Stress on first syllable unless otherwise noted. $\hat{V}=$ a rising tone; $\check{V}=$ a low rising tone.

\section{$\underline{\text { Gloss }}$}

232. seven

233. seventeen

234. sharp

235. six

236. sixteen

237. small

238. sour

239. ten

240. thirteen

241. thirty-nine

242. three

243. thousand

244. twelve

245. twenty

246. twenty-nine

247. two

\section{Kashmiri}

sat $^{\mathrm{h}}$
sadah
te:z
še
šurah
lokuṭ
tsok
dəh
truvah
kunitərdžih
tre
sa:s
bah
vuh
kunitrih
zi

$\underline{\text { Kishtawari }}$

$\mathrm{sat}^{\mathrm{h}}$

sa'dah

te:z

še

šu'dah

lo'kur

tsok

dəh

truvah

kun'tarlih

tre

sa:s

bah

uh

kun'tri:h

Zi
Poguli

sat

sa'dah

tesiz

šeh

šo'ḍah

lokts ${ }^{\mathrm{h}} \mathrm{u}$

tsuk $^{\mathrm{h}}$

dah

tro'vah

kun'ta:lih

cari

sais

bah

vih

kun'trih

dih $\underline{\text { Siraji }}$

sa:t ${ }^{b}$

sitar'ra:

no data

šah

šo'ra:

nik'ṛo

am'lo

daš

te:'ra:

unta:'li:

trei

ha'za:r

ba:'ra:

bi:

una'tri:

du'i 
TABLE 3: COMPARATIVE KASHMIRI VOCABULARIES

Stress on first syllable unless otherwise noted. $\hat{v}=$ a rising tone; $\check{v}=$ a low rising tone.

Gloss

248. white

249. yellow

XI. Pronouns etc.

250. he

251. I

252. not

253. she

254. they $m$. far

255. they $f$ far

256. they $m$. near

257. they $f$. near

258. that (thing)

259. that (person)

260. this (thing)

261. this (person)

262. we $\underline{\text { Kashmiri }}$

sap $^{\mathrm{h}} \mathrm{e:d}$

jodur

su

bi

$\mathrm{ni}$

so

tim

timi

yim

yimi

ti

su

yi

yi

$\partial \mathrm{s}^{\mathrm{j}}$ $\underline{\text { Kishtawari }}$

saferd

ljodur

hu, su

bo

no data

hu, s $\mathrm{s}^{\mathrm{j}}$

hum

hum

yim

yim

su, $s^{j} e$

$\mathrm{su}$

yi

yi

əs ${ }^{\mathrm{j}}$
Poguli

safæ:əd

lidru

su

aนũ

na

sa

t⿳亠㐅̃ $\tilde{u}$

ไãน̃ vah

t⿳亠̃̃

t๋ãนũ vah

sa

su

ya

yu

as $\underline{\text { Siraji }}$

$c^{\text {hit' to: }}$

hal'dro

tæṇə
aũ̃
na
tæ'ṇa
tæṇə
tæ'ṇa
æṇə
æṇə
tæṇ cìz
tæ ma:'ṇũ:
in cirz
in ma:'ṇũ:
arũ

tænว

tæuna

tæṇว

tæ'ṇa

ænว

æṇ

tæụ ci:z

tæ ma:'nũ̃:

in cirz

a:ũ 
TABLE 3: COMPARATIVE KASHMIRI VOCABULARIES

$\underline{\text { Gloss }}$ $\underline{\text { Kashmiri }}$

263. what?

265. who?

266. you $s g$.

267. you pl.

$\mathrm{k}^{\mathrm{j}} \mathrm{a}$

kus

tsi

$\operatorname{toh}^{\mathrm{j}}$ $\underline{\text { Kishtawari }}$

$\mathrm{k}^{\mathrm{j}} \mathrm{a}:$

k̃

tu

tus $^{\mathrm{j}}$ $\underline{\text { Poguli }}$

kut

kam

tu

tus $\underline{\text { Siraji }}$

ko:

$\mathrm{k}^{\mathrm{j}} \mathrm{e}$

tu

tur 